\title{
Eco-Efficient Cement-Based Materials Using Biomass Bottom Ash: A Review
}

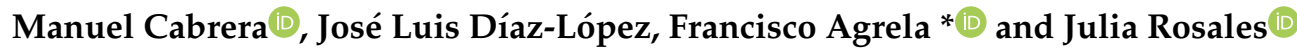 \\ Construction Engineering Area, University of Córdoba, 14014 Córdoba, Spain; manuel.cabrera@uco.es (M.C.); \\ ep2diloj@uco.es (J.L.D.-L.); jrosales@uco.es (J.R.) \\ * Correspondence: fagrela@uco.es
}

Received: 17 September 2020; Accepted: 27 October 2020; Published: 12 November 2020

\begin{abstract}
In recent years the use of biomass for electricity generation in thermal and cogeneration plants has increased worldwide because it is an environmentally clean fuel whose impact measured in greenhouse gas emissions is practically zero. However, biomass bottom ash, a waste produced during combustion, has also increased considerably, which has both a negative economic and environmental impact, due to landfill transport and management of this by-product. Although biomass bottom ash has potential characteristics for application in the manufacture of construction materials, its full-scale application is difficult because of the wide range in physicochemical properties, depending on the type of biomass burned, such as wood residue, olive waste, waste paper sludge, cocoa shell, etc., and the type of combustion process in the plant. This study reviews the influence on the physicochemical properties, mechanical behavior, and durability of different cement-based materials, such as mortars, concrete, and cement-treated granular material, manufactured from biomass bottom ash. The previous studies demonstrate the feasibility of substituting natural materials for biomass bottom ash in cement-based materials, presenting adequate mechanical behavior and durability properties to comply with the required technical specifications in different building materials.
\end{abstract}

Keywords: biomass bottom ash; cement-based materials; eco-efficient concrete; cement-treated granular materials; eco-efficient mortars

\section{Introduction}

More and more countries are now generating electricity from the direct combustion of biomass waste [1,2]. Biomass combustion is considered an important source of energy today, producing $14 \%$ of the world's energy supply [3]. Li et al. [4] estimate the high availability of biomass at 220 billion tons per year. Other world studies estimate that by 2100 , between $25 \%$ and $46 \%$ of energy from biomass combustion will be used [5].

Different technologies are used for biomass combustion. Modolo et al. [6] showed the most appropriate technology for biomass combustion, the so-called fluidized bed, mainly due to its versatility in the type of fuel it consumes. The technology used influences the characteristics of the biomass ash produced, with different properties depending on the type of biomass used for energy generation.

Two main types of ash are produced during energy generation process by biomass combustion: bottom ash and fly ash.

Bottom ash includes the coarse fraction of ash produced in the grill, in the lower bed, and in the primary combustion chamber. Normally it is mixed with mineral impurities contained in the biomass fuel and slag that has not fully combusted, whereas fly ash is the ash fraction with a smaller particle size, carried by the flue gas, which is collected and precipitated in filters $[7,8]$. 
Biomass combustion is considered a clean energy without $\mathrm{CO}_{2}$ emissions, therefore more plant facilities have been built in recent years [9]. This increase in biomass combustion power plants result in the amount of ash generated, without having a recycling alternative.

There are different works that have studied the use of biomass fly ash (BFA) as incorporation in the manufacture of new construction materials. The use of BFA in the manufacture of mortars has been studied [10-14]; the use of BFA in cements, conventional and self-compacting concrete has also been studied with positive results [15-17].

However, there are few studies in which biomass bottom ash (BBA) is incorporated into construction materials; its composition is very heterogeneous [7] so its application is more restricted. Maschio et al. [11] reported that the use of BBA in cement, mortar, or concrete is feasible. Beltran et al. [18] studied the mechanical behavior of mortars manufactured with BBA, both reporting interesting results when analyzing the influence of certain parameters on mechanical behavior and defining trends and relationships among the different properties. Other authors have studied the physical, chemical, and mechanical properties of conventional concrete made with BBA [19]. Cabrera et al. [20] showed the possibility of reusing BBA mixed with natural aggregates and recycled aggregates for cement-treated granular materials in road bases and sub-bases, and the possibility of stabilizing soil by reducing the use of lime [21].

The positive results obtained in the different works reveal the possibility of using BBA as an eco-efficient material, eliminating the negative impact of this waste on landfill.

In this work, a review of previous studies in which biomass bottom ash has been applied in cement-based materials, mortars, and concrete was analyzed. The different application possibilities were studied, from the characterization properties of different typologies of BBA, to the revision of the possibilities of applying them to these cement-based materials, including mechanical properties, durability, etc.

\section{Properties of BBA}

\subsection{Biomass Research}

Different studies report that BBA are heterogeneous mixes of particles, of variable size. Some of these ashes are cellular, unburned, or partially unburned ashes.

The main aspects that influence the characteristics of BBA are their origin, for example, herbaceous material, wood, bark, etc. [7]; in addition, combustion technology has a significant influence [22]. There are different types of biomass boiler and that we are going to detail below. For example: grill boiler, the operation of this type of boiler consists of circulating the biomass through a conveyor belt. Fluidized bed boiler, its operation is based on the creation of a fluid of inert material in suspension. Injection boiler, this technology is based on a high pulverization of the biofuel. Each type of boiler provides different types of BBAs.

BBA obtained from fir chips burnt in the power plant located in the Italian Region of Venezia were used by Maschio et al. [11] in mortar fabrication.

Modolo et al. [6] used BBA from the combustion of forest biomass, mainly eucalyptus barks, collected at the bottom of the bubbling fluidized bed combustor in a plant located in Portugal.

Beltran et al. [18,19], Rosales et al. [21,23], and Cabrera et al. [20,24] used BBA from a thermal plant in Linares, located in Andalusia, in the south of Spain. Biomass composed of $40 \%$ dry mass olive cake and $60 \%$ dry mass wood biomass (poplar, pine, and olive) were burnt by boiler at a temperature of $403^{\circ} \mathrm{C}$.

Lessard et al. [25] utilized BBA from biomass waste burnt on fluidized bed boiler at a cogeneration plant in Canada [26]. The biomass was compounded by a mix of waste paper sludge from the paper industry and wood waste. 
Fontes et al. [27] studied BBA from a thermal plant located in Ilhéus city, Brazil during the cleaning of the boilers. The biomass, which is burnt at about $300{ }^{\circ} \mathrm{C}$, consisted of wood chips $(80 \%)$ and cocoa shells $(20 \%)$.

Biomass from the boilers of three Spanish combustion power plant was studied by Medina et al. [28]. Wheat, rye, oat, and corn straw were burnt in two plants (named S1 and S2) and a mixture of $40 \%$ wood biomass and $60 \%$ straw waste were burnt in the third plant (S3).

Sklivaniti et al. [29] used BBA from the combustion of olive plants trimmings in a fixed-bed combustion system.

\subsection{Phisicochemical Properties}

Table 1 shows the main physical and chemical properties of BBA studied by different authors for its application in the manufacture of mortars, concrete, or cement-treatment granular material. 
Table 1. Physical and chemical properties of Biomass Bottom Ash (BBA) by authors.

\begin{tabular}{|c|c|c|c|c|c|c|c|c|c|c|c|c|c|}
\hline $\begin{array}{l}\text { BBA by } \\
\text { Author }\end{array}$ & $\begin{array}{c}\text { Maschio et al. } \\
\text { [11] }\end{array}$ & $\begin{array}{c}\text { Modolo et al. } \\
{[6]}\end{array}$ & $\begin{array}{c}\text { Beltran et al. } \\
{[18]}\end{array}$ & $\begin{array}{c}\text { Rosales et al. } \\
\text { [21] }\end{array}$ & $\begin{array}{l}\text { Beltrán et al. } \\
\text { [19] }\end{array}$ & $\begin{array}{l}\text { Lessard et al. } \\
{[25]}\end{array}$ & $\begin{array}{c}\text { Fontes et al. } \\
{[27]}\end{array}$ & $\begin{array}{c}\text { Rosales et al. } \\
\text { [23] }\end{array}$ & $\begin{array}{c}\text { Cabrera et al. } \\
{[7]}\end{array}$ & $\begin{array}{c}\text { Cabrera et al. } \\
{[20]}\end{array}$ & $\begin{array}{c}\text { Carrasco et al. } \\
{[30]}\end{array}$ & $\begin{array}{c}\text { Medina et al. } \\
{[28]}\end{array}$ & $\begin{array}{c}\text { Sklivanitiv et al } \\
\text { [29] }\end{array}$ \\
\hline Origin of $B B A$ & $\begin{array}{l}\text { Wood Biomass } \\
\text { (Fir chips) }\end{array}$ & $\begin{array}{l}\text { Forest Biomass } \\
\text { (Eucalyptus } \\
\text { Bark) }\end{array}$ & $\begin{array}{l}\text { Olive Waste } \\
\text { and Wood } \\
\text { Biomass }\end{array}$ & $\begin{array}{l}\text { Olive Waste } \\
\text { and Wood } \\
\text { Biomass }\end{array}$ & $\begin{array}{l}\text { Olive Waste } \\
\text { and Wood } \\
\text { Biomass }\end{array}$ & $\begin{array}{c}\text { Wood Biomass } \\
\text { and Waste } \\
\text { Paper Sludge }\end{array}$ & $\begin{array}{l}\text { Wood Chips } \\
\text { and Cocoa } \\
\text { Shell }\end{array}$ & $\begin{array}{l}\text { Olive Waste } \\
\text { and Wood } \\
\text { Biomass }\end{array}$ & $\begin{array}{l}\text { Olive Waste } \\
\text { and Wood } \\
\text { Biomass }\end{array}$ & $\begin{array}{l}\text { Olive Waste } \\
\text { and Wood } \\
\text { Biomass }\end{array}$ & $\begin{array}{l}\text { Olive Waste } \\
\text { and Wood } \\
\text { Biomass }\end{array}$ & $\begin{array}{l}\text { Wheat, Rye, } \\
\text { Oat, Corn } \\
\text { Straw and } \\
\text { Straw Waste }\end{array}$ & $\begin{array}{c}\text { Olive } \\
\text { Trimmings }\end{array}$ \\
\hline \multicolumn{14}{|l|}{$\begin{array}{c}\text { Physical } \\
\text { Properties }\end{array}$} \\
\hline $\begin{array}{c}\text { Density SSD } \\
\left(\mathrm{kg} / \mathrm{dm}^{3}\right)\end{array}$ & 2.60 & 2.65 & 1.67 & 1.86 & 2.02 & 2.31 & 2.52 & 1.97 & 2.46 & 1.82 & 2.35 & 2.35 & \\
\hline $\begin{array}{c}\text { Water } \\
\text { Absortion (\%) }\end{array}$ & - & - & 19.00 & 21.18 & 19.9 & 5.25 & - & 26.60 & 20.11 & 31.99 & - & - & \\
\hline $\begin{array}{l}\text { Absortion (\%) } \\
\text { Size (mm) }\end{array}$ & - & - & $0-2$ & $0-4$ & $0-2$ & $0-1$ & $0-0.6$ & $0-10$ & $0-10$ & $0-10$ & $0-0.1$ & $0-0.1$ & \\
\hline \multicolumn{14}{|l|}{$\begin{array}{l}\text { Chemical } \\
\text { properties }\end{array}$} \\
\hline $\mathrm{CaO}(\%)$ & 48.40 & 17.15 & 19.75 & 16.57 & - & 23.7 & 8.3 & 23.9 & 23.48 & 22.88 & 29.96 & $9-12$ & 31.41 \\
\hline $\mathrm{SiO}_{2}(\%)$ & 14.80 & 72.18 & 48.20 & 55.50 & - & 44.8 & 10.2 & 52 & 53.79 & 46.79 & 27.87 & $49-64$ & 6.84 \\
\hline $\mathrm{K}_{2} \mathrm{O}(\%)$ & 11.10 & 5.54 & 15.78 & 7.67 & - & 2 & 32.2 & 18.8 & 17.20 & 17.71 & 23.22 & - & 12.31 \\
\hline $\mathrm{MgO}(\%)$ & 9.90 & 1.96 & 3.94 & 2.64 & - & 2 & 15.8 & 1.4 & 1.86 & 1.52 & 4.05 & - & 2.45 \\
\hline $\mathrm{SO}_{3}(\%)$ & -9.90 & 1.96 & 0.94 & ${ }^{2.04}$ & - & 4.6 & $\begin{array}{l}1.3 .8 \\
1.3\end{array}$ & 1.4 & 1.80 & 1.52 & $\begin{array}{l}4.05 \\
0.76\end{array}$ & - & $\begin{array}{l}2.45 \\
0.14\end{array}$ \\
\hline $\begin{array}{l}\mathrm{SU}_{3}(\%) \\
\mathrm{Fe}_{2} \mathrm{O}_{3}(\%)\end{array}$ & - & - & - & & - & $\begin{array}{l}4.6 \\
4.8\end{array}$ & $\begin{array}{l}1.3 \\
2.8\end{array}$ & 0.7 & 1.15 & 1.29 & $\begin{array}{l}0.76 \\
3.59\end{array}$ & - & $\begin{array}{l}0.14 \\
1.39\end{array}$ \\
\hline $\mathrm{Al}_{2} \mathrm{O}_{3}(\%)$ & 3.20 & 2.29 & 1.42 & 5.39 & - & 11.5 & 1.6 & 1.9 & 0.40 & 0.43 & 4.34 & - & 2.73 \\
\hline $\mathrm{TiO}_{2}(\%)$ & & & & & - & & 0.29 & 0.2 & 0.08 & 0.08 & 0.35 & - & - \\
\hline $\mathrm{Na}_{2} \mathrm{O}(\%)$ & 1.00 & 0.88 & 0.51 & 0.28 & - & 1.8 & & 0.2 & 0.26 & 0.20 & 0.35 & - & 0.11 \\
\hline LOI (\%) & - & - & & - & - & 1.9 & 15.3 & - & 15.50 & - & - & - & 42.00 \\
\hline $\begin{array}{c}\text { Soluble } \\
\text { Sulphate (\%) }\end{array}$ & - & - & 0.27 & 0.31 & 0.47 & - & - & 0.41 & 0.39 & 0.35 & - & - & - \\
\hline $\begin{array}{l}\text { Organic matter } \\
\text { content }(\%)\end{array}$ & - & - & 5.26 & 4.34 & 3.06 & - & - & 4.12 & 4.89 & 4.85 & - & - & - \\
\hline
\end{tabular}


BBA particles generally have a lower density and higher absorption than natural materials such as sand and the particle size varies depending on the type of furnace $[7,22,31]$; this is due to the general aspect and morphology of BBA, which usually have angular shapes and rough textures, as shown in Figure 1.

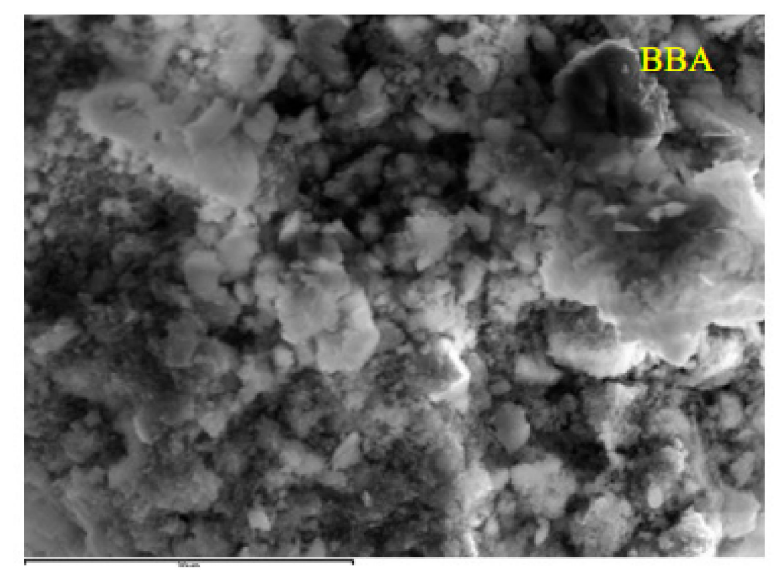

Figure 1. SEM picture of BBA from Cabrera et al. [24].

The chemical composition of BBA varies considerably depending on the combustion temperatures and type of biomass [32], presenting different phases, which influence the density and absorption of the particles, which explains the range of values obtained by different authors.

BBA from forestry biomass and waste from the olive industry usually have high percentages of $\mathrm{CaO}$ and $\mathrm{SiO}_{2}$ [33] and to a lesser extent by magnesium, aluminum, and potassium oxides. The ash from plants with long reproductive periods, such as trees, have a very different mineral composition from plants that are harvested several times a year, such as cereals, due to the dynamics of nutrient flow with the soil. The latter contain higher amounts of oxides particularly potassium and phosphorus.

In addition, previous studies have verified that the composition of ashes produced at the same thermal plant are notably homogeneous [22], which contrasts with the data provided by Rosales et al. [21,23], Beltrán et al. [18,19], Cabrera et al. [20,24], and Carrasco et al. [30]. Therefore, it cannot be said that the ashes generated are homogeneous, as this depends on the plant being analyzed. BBA can substantially change its composition in different periods of energy production.

The studies analyzed showed that the material or waste from BBA results in a quite different composition of ashes [21-24]. BBA from waste paper sludge has very high $\mathrm{SiO}_{2}$ and $\mathrm{CaO}$ value and $\mathrm{Al} 2 \mathrm{O} 3$ moderate value which is consistent with previous studies by different authors [34].

BBA analyzed by Fontes et al. [27] (generated in the cocoa industry) has a very low value of $\mathrm{SiO}_{2}$ and $\mathrm{CaO}$ and a very high $\mathrm{K}_{2} \mathrm{O}$ and $\mathrm{MgO}$ value, which indicates that BBA from cocoa shell and wood chips are not pozzonalic. The $\mathrm{MgO}$ rich composition is consistent with other studies of ash from wood residues and agricultural crops [32]; in addition, high levels of potassium have also been identified in other biomass ash from the oleoresin industry [35] and in ash from nutshells with a high lipid content [36].

According to the X-ray diffraction patterns shown in Figure 2, it can be observed that BBA analyzed by Cabrera et al. [7] which come from the thermal plant in Linares [7,18,21,30] are composed of two main elements: calcite $(\mathrm{CaO})$ and quartz $\left(\mathrm{SiO}_{2}\right)$. 


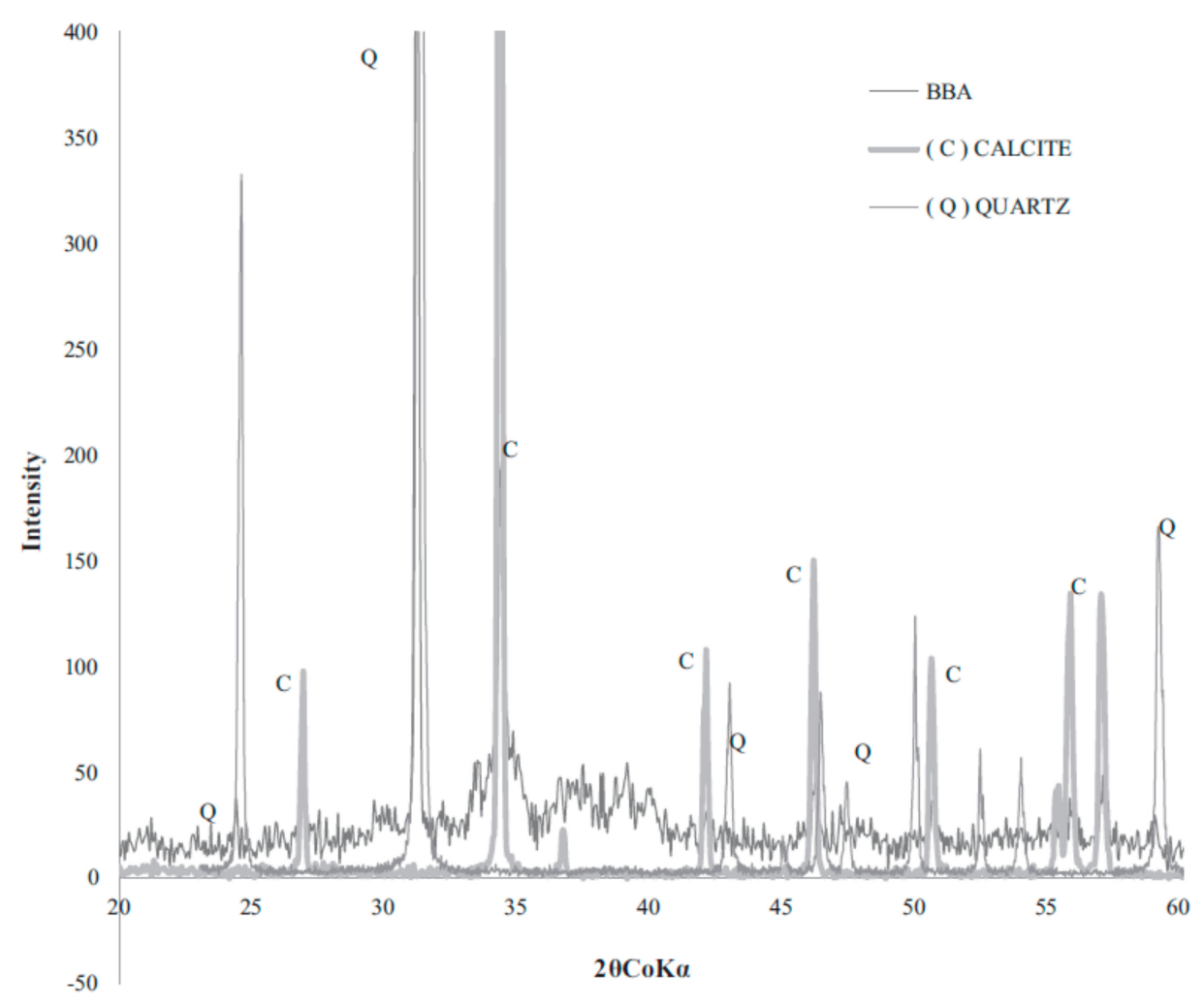

Figure 2. X-ray diffraction of BBA from olive waste in South of Spain. Cabrera et al. [7].

Similarly, BBA from Olive trimmings analyzed by Sklivaniti et al. [29] present a composition mainly of Calcite (about 70\%) followed by other phases in lesser quantity such as quartz or Fairchildite $\left(\mathrm{K}_{2} \mathrm{CaCO}_{3}\right)$. BBA analyzed by Medina et al. [28] present high percentages of Calcite and medium-low quartz value, typical values in BBA obtained from combustion of straw corn [32].

BBA from waste paper sludge show that quartz is the mainly phase, followed by other minerals such as calcite or anhydrite.

Finally, BBA from cocoa shell and wood chips $\mathrm{X}$-ray diffraction patterns show the main component of ash was gismondite $\left(\mathrm{CaAl}_{2} \mathrm{Si}_{2} \mathrm{O}_{8} \cdot 4 \mathrm{H}_{2} \mathrm{O}\right)$. Other phases such as $\mathrm{MgO}, \mathrm{Ca}_{2} \mathrm{SiO}_{4}$, and $\mathrm{Mg}_{2} \mathrm{P}_{2} \mathrm{O}_{7}$ were identified to a lesser extent.

Additionally, another important property for its later use as construction material is the percentage of organic matter. It is important to note that this factor depends directly on the type of combustion system used by each biomass combustion plant. The amount of organic matter is a consequence of the combustion efficiency and, in order to reduce this organic matter content, it is advisable to use raw materials with low density and low moisture [22,37].

This work focuses mainly on a review of the results obtained in the application of biomass bottom ash to cement-based materials. Unlike fly ash, which has been widely studied, BBAs have been studied only for application in mortars, concrete, and as a soil stabilizer.

Below, the most relevant results obtained on the application of these wastes in these three construction materials are presented.

\section{Biomass Bottom Ash in Mortars}

The use of ash from biomass combustion is conditioned by its physical-chemical properties. There are not many studies that include the use of BBA in construction materials, especially in cement-based materials. Analyzing the origin of the BBA, those that have been mainly used in construction materials are the ones that come from olive waste or other types of trees. The studies 
carried out to date have shown the possibility of using BBA with a high silica and calcium content in the manufacture of cement mortars.

Maschio et al. [11] worked on the manufacture of mortars using commercial CEM II/B-LL cement, sand, and bottom ash from spruce chips. Ash was added in various proportions as cement weight replacement $(5 \%, 10 \%, 20 \%, 30 \%)$, to study its cementing capacity, pozzolanicity, or hydraulicity.

Modolo et al. [6] used BBA from forest residues as an aggregate in the formulation of mortars with a $50 \%$ and $100 \%$ by weight replacement of commercial sand for BBA. The authors used two different conditions. On the one hand, it manufactured a series sieving the BBA between 250 and $1000 \mu \mathrm{m}$, adjusting the particle size curve to that of the commercial sand frequently used in the formulation of mortars. On the other hand, with the intention of reducing the percentage of soluble salts, the BBA were washed and sieved.

Beltrán et al. [18] studied the mechanical behavior of mortars made with BBA and the influence of different variables on their production, such as the type of cement (CEM II 32.5 R, CEM I/N-SR), content of cement $(515,485$, and $450 \mathrm{~g} / \mathrm{L})$ and the percentage of BBA replacement. Three volumetric replacement ratios were applied from BBA $(0 \%, 10 \%$, and $20 \%)$. Standardized sand and cement were substituted by BBA. The authors reported that different behaviors were reproduced according to the type of cement or the type of material replaced; in addition, the BBAs had a low density and high absorption that was reflected in the variability of the strength of the mortars.

Carrasco et al. [30] studied physicochemical and mineralogical properties of compacted building blocks made from Portland cement (OPC) and BBA. OPC were replaced by BBA in a range from $10 \%$ to $90 \%$.

Medina et al. [28] designed new cement formulations replacing $10 \%$ and $20 \%$ of clinker by BBA. The results drawn by the authors show that the new cement properties are not significantly worsened, present lesser shrinkage and swelling, and similar mechanical behavior.

Sklivanitiv et al. [29] analyzed the effect of different OPC replacement by BBA $(2,3,5,7$, and 10 $\mathrm{wt} \%$ ) in mortar mixtures, concluding the BBA could be used in recycled cement until 42.5 class obtained similar mechanical behavior than the mixtures without bottom ashes.

Rosales et al. [21] studied the mechanical and durability properties of mortars made with BBA using different processing methods; there were a total of eight treatments: raw, crushed, calcined, without light particles, crushed and calcined, crushed and without particles light, calcined and without light particles, and finally, crushed-calcined and without light particles.

Cement was replaced with different BBA substitution rates. The results showed significant improvements in the mechanical properties and durability of the mortars in which some treatments were applied.

\subsection{Dosages}

There are different regulations for the manufacture of mortars, the most common being: ASTM C270-19ae1 [38], ASTM C305-14 [39], EN 1015-2: 1998 [40], and EN 196-1: 2018 [41].

Maschio et al. [11] used ASTM C305-14 [39] for the preparation of mixes. Modolo et al. [6] manufactured bricklaying mortars according to EN 1015-2: 1998 [40] and Beltrán et al. [18] and Rosales et al. [21], Sklivaniti et al. [29], and Medina et al. [28] used the EN 196-1: 2018 standard [41]. Carrasco et al. [30] manufactured cement blended according EN-standard 772-16:2011 [42].

The dosage used by these authors is shown in Table 2.

Table 2 shows the different dosages used by some authors. Modolo et al. [6] replaced 10\% and 20\% of natural sand (NS) with BBA in percentage of dry weight. Beltran et al. [18] used three volumetric replacement ratios of natural sand (NS) and cement (CEM) with BBA $(0 \%, 10 \%$, and $20 \%)$ and three cement contents $(515 \mathrm{~g} / \mathrm{L}, 485 \mathrm{~g} / \mathrm{L}$ and, $450 \mathrm{~g} / \mathrm{L})$. Finally, Rosales et al. [21] made mortars according to the particle size of the BBA, substituted cement for BBA and used crushed BBA (C) without light particles (NL), combusted calcined (CO), as well as the combination of all treatments. Replacements were carried out in volume. 
Table 2. Mortar mix proportions.

\begin{tabular}{|c|c|c|c|c|c|c|c|}
\hline \multicolumn{8}{|c|}{ Mortar (Sand, Cement, Water, and BBA) } \\
\hline & Mixtures & & & BBA & Sand & Water & Admixture \\
\hline \multirow{3}{*}{$\begin{array}{l}\text { Modolo et al. [6] } \\
\text { (wt\% replacement) }\end{array}$} & Control-1 & 14 & \multirow{3}{*}{$\begin{array}{c}\text { CEM-I } \\
42.5 \mathrm{R}\end{array}$} & 0 & 20 & 16.5 & 0 \\
\hline & BBA-2 & 14 & & 10 & 10 & 16.5 & 0 \\
\hline & BBA-3 & 14 & & 20 & 45 & 16.5 & 0 \\
\hline \multirow{11}{*}{$\begin{array}{l}\text { Beltrán et al. [18] (g) } \\
\text { (vol\% replacement) }\end{array}$} & Control-4 & 515 & \multirow{11}{*}{$\begin{array}{c}\text { CEM-I } \\
52.5 \mathrm{~N} / \mathrm{SR}\end{array}$} & 0 & 1541 & 258 & 0 \\
\hline & BBA-5 & 515 & & 79 & 1387 & 258 & 1 \\
\hline & BBA-6 & 515 & & 158 & 1233 & 258 & 1.6 \\
\hline & Control-7 & 485 & & 0 & 1605 & 243 & 0.2 \\
\hline & BBA-8 & 485 & & 82 & 1444 & 243 & 1.8 \\
\hline & BBA-9 & 485 & & 165 & 1284 & 243 & 2.22 \\
\hline & BBA-10 & 485 & & 32 & 1541 & 243 & 0.4 \\
\hline & Control-11 & 450 & & 0 & 1682 & 225 & 0.5 \\
\hline & BBA-12 & 450 & & 86 & 1514 & 225 & 2.25 \\
\hline & BBA-13 & 450 & & 173 & 1345 & 225 & 3 \\
\hline & BBA-14 & 450 & & 72 & 1541 & 225 & 0.6 \\
\hline \multirow{8}{*}{$\begin{array}{l}\text { Rosales et al. }[21](\mathrm{g}) \\
\text { (vol\% replacement) }\end{array}$} & Control-15 & 450 & \multirow{8}{*}{$\begin{array}{c}\text { CEM-I } \\
52.5 \mathrm{~N} / \mathrm{SR}\end{array}$} & 0 & 1350 & 225 & 0 \\
\hline & BBA-16 & 365 & & 53.01 & 1350 & 225 & 1.7 \\
\hline & $\begin{array}{c}* \\
\text { BBA-17-CO-NL }\end{array}$ & 365 & & 57.86 & 1350 & 225 & 2.7 \\
\hline & ${ }^{*}$ BBA-18-C & 365 & & 53.87 & 1350 & 225 & 1.9 \\
\hline & $\stackrel{*}{*}$ & 365 & & 60.42 & 1350 & 225 & 3.6 \\
\hline & BBA-20 & 280 & & 102.3 & 1350 & 225 & 3.1 \\
\hline & $\stackrel{*}{*}$ BBA-21-CO-NL & 280 & & 111.65 & 1350 & 225 & 4.6 \\
\hline & $\stackrel{*}{*}$ BBA-23-C-CO-NL & 280 & & 116.6 & 1350 & 225 & 5.9 \\
\hline${ }^{*} \mathrm{BBA}-\mathrm{CO}-\mathrm{NL}$ & \multicolumn{7}{|c|}{ Mortar with Combusted BBA (Without Lightweight Particles) } \\
\hline * BBA-C & \multicolumn{7}{|c|}{ Mortar with Crushed BBA } \\
\hline * BBA-C-CO-NL & \multicolumn{7}{|c|}{ Mortar with Crushed and Combusted BBA (Without Lightweight Particles) } \\
\hline \multirow{9}{*}{$\begin{array}{c}\text { Medina et al. [28] } \\
\text { (g) (wt } \% \\
\text { Replacement) }\end{array}$} & Control-28 & 450 & \multirow{7}{*}{$\begin{array}{l}\text { CEM I } \\
42.5 \mathrm{R}\end{array}$} & 0 & 1350 & 225 & 0 \\
\hline & BBA-29 & 405 & & 45 & 1350 & 225 & 0 \\
\hline & BBA-30 & 360 & & 90 & 1350 & 225 & 0 \\
\hline & BBA-31 & 405 & & 45 & 1350 & 225 & 0 \\
\hline & BBA-32 & 360 & & 90 & 1350 & 225 & 0 \\
\hline & BBA-33 & 405 & & 45 & 1350 & 225 & 0 \\
\hline & BBA-34 & 360 & & 90 & 1350 & 225 & 0 \\
\hline & \multicolumn{7}{|c|}{ Mortar (Cement, Water, and BBA) } \\
\hline & Mixtures & & & BBA & & Water & Admixture \\
\hline \multirow{11}{*}{$\begin{array}{l}\text { Carrasco et al. [30] } \\
\text { (wt\% Replacement) }\end{array}$} & Control-35 & 100 & \multirow{11}{*}{$\begin{array}{c}\text { CEM II } \\
\text { A-L } 32.5\end{array}$} & 0 & & 14 & 0 \\
\hline & BBA-36 & 90 & & 10 & & 5.4 & 0 \\
\hline & BBA-37 & 80 & & 20 & & 4.77 & 0 \\
\hline & BBA-38 & 70 & & 30 & & 5.6 & 0 \\
\hline & BBA-39 & 60 & & 40 & & 7.9 & 0 \\
\hline & BBA-40 & 50 & & 50 & & 8.23 & 0 \\
\hline & BBA-41 & 40 & & 60 & & 9.16 & 0 \\
\hline & BBA-42 & 30 & & 70 & & 8.54 & 0 \\
\hline & BBA-43 & 20 & & 80 & & 7.15 & 0 \\
\hline & BBA-44 & 10 & & 90 & & 8.25 & 0 \\
\hline & BBA-45 & 0 & & 100 & & 12 & 0 \\
\hline \multirow{6}{*}{$\begin{array}{l}\text { Sklivaniti et al. [29] } \\
\text { (wt\% Replacement) }\end{array}$} & Control-46 & 100 & \multirow{6}{*}{$\begin{array}{l}\text { CEM I } \\
52.5 \mathrm{~N}\end{array}$} & 0 & & 26.6 & 0 \\
\hline & BBA-47 & 98 & & 2 & & 27.4 & 0 \\
\hline & BBA-48 & 97 & & 3 & & 28.2 & 0 \\
\hline & BBA-49 & 95 & & 5 & & 29.2 & 0 \\
\hline & BBA-50 & 93 & & 7 & & 31.75 & 0 \\
\hline & BBA-51 & 90 & & 10 & & 32.4 & 0 \\
\hline
\end{tabular}




\subsection{Mechanical Properties}

Table 3 shows the compressive strength of mortars made with BBA at different cure ages. Modolo et al. [6] reported the strength at 7 and 28 days of curing, obtaining a slight increase in the series that incorporated BBA compared to the Control mortar.

On the contrary, Beltran et al. [18] and Rosales et al. [21] manufactured specimens of $40 \times 40 \times 160 \mathrm{~mm}$ and used EN196-1 [41] standard to obtain the compressive strength values. Both studies show that the compressive strength gradually decreased with the incorporation of BBA, mainly because the pozzolanic activity of BBA is lower than that of cement, this produces a reduction in strength. However, samples made by Carrasco et al. [30] were manufactured applying uniaxial loads of $20 \mathrm{MPa}$ during 30s, resulting in a very high compactness specimens which present a better compressive strength than control sample with a replacement of $50 \%$ of OPC by BBA.

However, Rosales et al. [21] used different treatments to incorporate BBA with very positive results from the mechanical behavior point of view.

Medina et al. [28] and Sklivaniti et al. [29] reported a drop in the mechanical behavior due to the replacement of OPC by BBA, nevertheless, that drop is more obvious in the samples made by Sklivaniti et al. [29] probably due to the differences between the dosages.

Finally, Machio et al. [11] reported that the 5\% incorporation by weight of BBA did not affect compressive strength compared to the reference mortar, although a higher percentage of BBA decreases the mechanical properties significantly.

The use of BBA in the manufacture of mortar increases the porosity, as a consequence of porosity, decreases density and reduces mechanical strength. The different studies agree that the negative effect on mechanical properties is due to the content of organic matter content present in BBA.

In general, BBA produce mixes of greater consistency, thus requiring higher water content. In order to maintain the water/cement ratio, the use of superplasticizers is required to reduce water demand. Additionally, the setting time increases with the incorporation of BBA.

The influence of biomass bottom ash is lower in mortars made with CEM-I. It can be concluded that the incorporation of up to $20 \%$ of BBA in the manufacture of mortars reduces its mechanical behavior values between $30 \%$ and $50 \%$ compared to a reference mortar made with natural aggregates and cement (Figure 3).

However, it has been shown that with a calcination treatment the mechanical properties can be improved, mainly by the reduction of organic matter content [22]. This factor could be avoided if the electricity generation plants by means of biomass combustion were more efficient in their combustion and thus eliminate a higher percentage of organic matter.

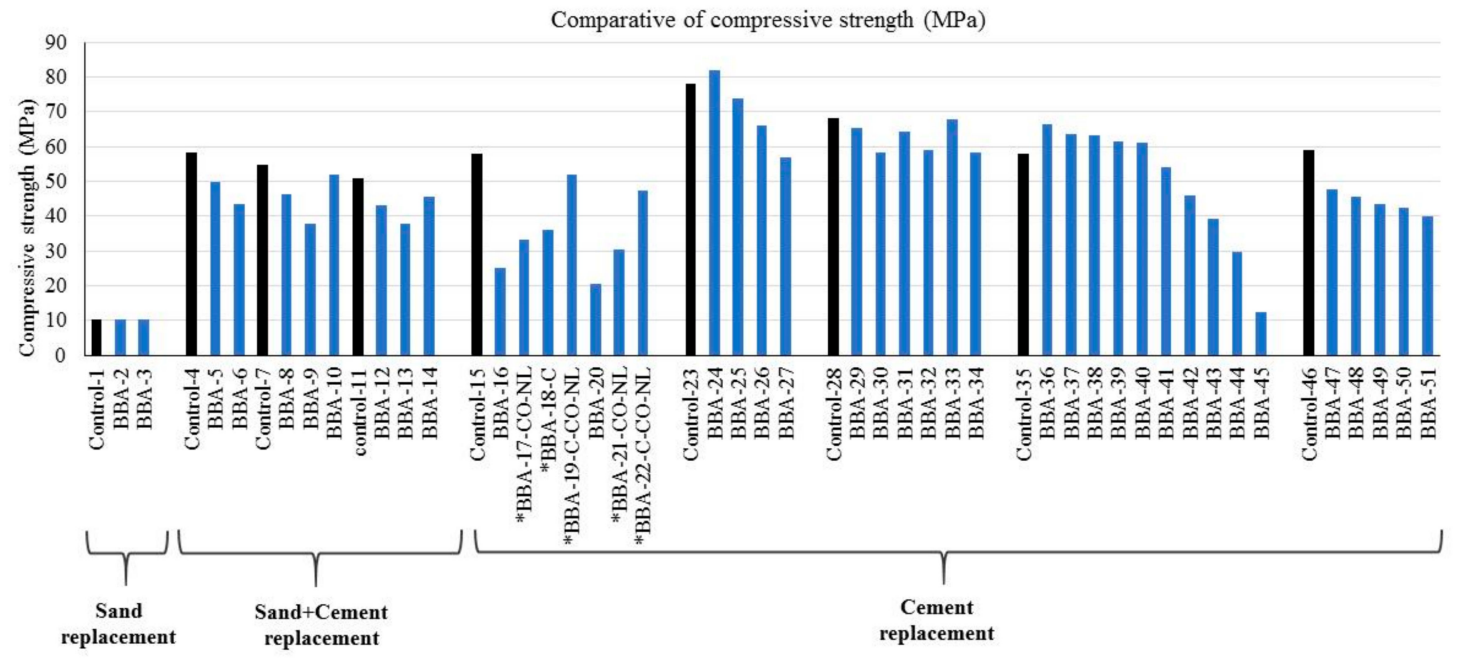

Figure 3. Comparative of compressive strength (Modolo et al. [6], Beltran et al. [18], Rosales et al. [21], Machio et al. [11], Medina et al. [28], Carrasco et al. [30], Sklivaniti et al. [29]). 
Table 3. Compressive strength.

\begin{tabular}{|c|c|c|c|c|c|c|}
\hline & & \multicolumn{5}{|c|}{$\begin{array}{c}\text { Compressive Strength (MPa) } \\
\text { Days }\end{array}$} \\
\hline & & 1 & 7 & 28 & 90 & 180 \\
\hline & & \multicolumn{5}{|c|}{ Mortar (Sand, Cement, Water, and BBA) } \\
\hline \multirow{3}{*}{ Modolo et al. [6] } & Control-1 & - & 6.8 & 10.2 & - & - \\
\hline & BBA-2 & - & 7.5 & 10.2 & - & - \\
\hline & BBA-3 & - & 7.8 & 10.3 & - & - \\
\hline \multirow{11}{*}{ Beltrán et al. [18] } & Control-4 & 27.83 & 51.22 & 58.26 & 60.12 & - \\
\hline & BBA-5 & 24.91 & 41.5 & 49.95 & 52.12 & - \\
\hline & BBA-6 & 21.2 & 36.65 & 43.59 & 45.25 & - \\
\hline & Control-7 & 26.26 & 50.5 & 54.89 & 57.25 & - \\
\hline & BBA-8 & 21.98 & 36.42 & 46.37 & 48.47 & - \\
\hline & BBA-9 & 19.24 & 31.32 & 37.96 & 39.98 & - \\
\hline & BBA-10 & 22.72 & 40.74 & 52.06 & 54.14 & - \\
\hline & Control-11 & 24.41 & 47.39 & 50.74 & 52.44 & - \\
\hline & BBA-12 & 18.7 & 34.17 & 43.01 & 45.85 & - \\
\hline & BBA-13 & 18.19 & 28.9 & 37.9 & 40.25 & - \\
\hline & BBA-14 & 21.02 & 41.89 & 45.54 & 47.69 & - \\
\hline \multirow{8}{*}{ Rosales et al. [21] } & Control-15 & 20.31 & 48.29 & 58.03 & 62.09 & - \\
\hline & BBA-16 & 10.08 & 19.54 & 25.12 & 28.46 & - \\
\hline & * BBA-17-CO-NL & 15.58 & 27.06 & 33.21 & 38.87 & - \\
\hline & * BBA-18-C & 11.01 & 29.56 & 36.18 & 41.87 & - \\
\hline & * BBA-19-C-CO-NL & 19.18 & 44.12 & 51.96 & 54.34 & - \\
\hline & BBA-20 & 5.26 & 17.51 & 20.63 & 23.47 & - \\
\hline & * BBA-21-CO-NL & 15.54 & 25.49 & 30.47 & 34.36 & - \\
\hline & * BBA-22-C-CO-NL & 17.06 & 39.42 & 47.28 & 49.64 & - \\
\hline \multirow{5}{*}{ Machio et al. [11] } & Control-23 & - & - & 78 & - & 83 \\
\hline & BBA-24 & - & - & 82 & - & 56 \\
\hline & BBA-25 & - & - & 74 & - & 49 \\
\hline & BBA-26 & - & - & 66 & - & 38 \\
\hline & BBA-27 & - & - & 57 & - & 34 \\
\hline \multirow{8}{*}{ Medina et al. [28] } & Control-28 & - & - & 68.22 & - & - \\
\hline & BBA-29 & - & - & 65.35 & - & - \\
\hline & BBA-30 & - & - & 58.35 & - & - \\
\hline & BBA-31 & - & - & 64.26 & - & - \\
\hline & BBA-32 & - & - & 59.01 & - & - \\
\hline & BBA-33 & - & - & 67.84 & - & - \\
\hline & BBA-34 & - & - & 58.17 & - & - \\
\hline & & \multicolumn{5}{|c|}{ Mortar (Cement, Water, and BBA) } \\
\hline \multirow{11}{*}{ Carrasco et al. [30] } & Control-35 & - & - & 58.11 & - & - \\
\hline & BBA-36 & - & - & 66.58 & - & - \\
\hline & BBA-37 & - & - & 63.46 & - & - \\
\hline & BBA-38 & - & - & 63.44 & - & - \\
\hline & BBA-39 & - & - & 61.63 & - & - \\
\hline & BBA-40 & - & - & 61.11 & - & - \\
\hline & BBA-41 & - & - & 54.16 & - & - \\
\hline & BBA-42 & - & - & 45.82 & - & - \\
\hline & BBA-43 & - & - & 39.30 & - & - \\
\hline & BBA- 44 & - & - & 29.86 & - & - \\
\hline & BBA-45 & - & - & 12.41 & - & - \\
\hline \multirow{6}{*}{ Sklivaniti et al. [29] } & Control-46 & 18.6 & 45.4 & 59.1 & - & - \\
\hline & BBA- 47 & 13.4 & 37.3 & 47.9 & - & - \\
\hline & BBA- 48 & 13.6 & 36.9 & 45.6 & - & - \\
\hline & BBA-49 & 14.1 & 33.4 & 43.4 & - & - \\
\hline & BBA-50 & 14.2 & 33.3 & 42.6 & - & - \\
\hline & BBA-51 & 15.1 & 32.1 & 40.05 & - & - \\
\hline
\end{tabular}




\section{Biomass Bottom Ash in Concrete}

In recent years, some authors have studied the manufacture of concrete with BBA due to its potential use as a substitute for materials such as natural sand or cement.

Beltrán et al. [19] studied the mechanical and durability properties of nonstructural concrete made with BBA from olive waste and recycled aggregates. Nine batches were made, divided into three groups depending on the percentage of substitution of natural sand by BBA $(0 \%, 3 \%$, and $6 \%)$ and the type of coarse aggregate used (natural aggregate, recycled concrete aggregate, or mixed recycled aggregate). In addition, a super-plasticizer additive was added, due to the high water absorption of the BBA, in order to maintain the workability. The results shown indicate a worse mechanical and durability behavior of the concrete made with BBA and recycled aggregates than the concrete made with natural aggregates. However, the series manufactured with BBA and natural aggregate, shows compressive strength values of up to $35 \mathrm{MPa}$ with $6 \%$ substitution of NA by BBA, and acceptable durability values, which indicates the real possibility of using this by-product in concrete manufacturing.

Lessard et al. [25] analyzed the feasibility of manufacturing roller-compacted concrete (RCC) and paver-compacted concrete (PCC) made with BBA from the combustion of waste from the paper industry and wood biomass. BBA was used as a replacement for natural sand in three different percentages $(0 \%, 50 \%$, and $100 \%)$ in both types of concrete. Furthermore, to the six mixes were added a water-reducing agent and an air-entraining agent, in order to control the workability properties of fresh concrete. The properties of fresh and hardened concrete properties were studied for both types of concrete, RCC and PCC. It was observed that compactness is an essential factor in the manufacture of RCC and PCC with BBA, since its use implies a high demand for water to maintain adequate workability and reduce porosity.

Fontes et al. [27] studied the manufacture of conventional concrete made with BBA from cocoa shell and wood chips as a replacement of cement. The concrete was manufactured using BBA with two treatments: sieved, to remove larger particles than $600 \mu \mathrm{m}$ and sieved and crushed (GBBA), to obtain a higher degree of fineness. With both processes, concrete made with substitutions in two percentages of BBA ( $5 \%$ and $10 \%$ ) were analyzed. The physical properties and mechanical behavior of the concrete were studied, observing how the composition of the ashes and their low puzzolanity have a great influence on them.

Rosales et al. [23] worked on the possibility of manufacturing lightweight recycled concrete (LRC) with BBA (from olive cake and wood biomass) and mixed recycled aggregates, taking advantage of the lower density of these materials than natural aggregates. Several mixes were made with different substitutions of natural aggregates and lightweight aggregates by BBA and mixed recycled aggregates (MRA), in order to study the workability, mechanical behavior, and durability of the LRC. The results showed a decrease in the characteristics of the concrete made with BBA and MRA; however, all the series manufactured with the different dosages presented compressive strength values within the limits established by the Spanish regulation, (EHE-08) [43] for lightweight structural concrete.

\subsection{Dosages and Mix Proportions}

In this section the concrete mix proportions of the different types of concrete made with BBA, such as nonstructural concrete [19], conventional concrete [27], roller-compacted concrete (RCC), and paver-compacted concrete (PCC) [25] or lightweight concrete (LRC) [23], were analyzed.

The proportions of materials used in the manufacture of concrete (dosage) are a fundamental parameter to achieve the appropriate workability, mechanical behavior, and durability properties depending on the type of concrete to be manufactured. Table 4 shows the different dosages used by the authors. 
Table 4. Concrete mix proportions by authors.

\begin{tabular}{|c|c|c|c|c|c|c|c|c|}
\hline \multirow[t]{2}{*}{ Mixes } & Cement & BBA & RA & $\begin{array}{l}\text { Natural } \\
\text { Sand }\end{array}$ & $\begin{array}{c}\text { Coarse } \\
\text { Aggregate }\end{array}$ & $\begin{array}{l}\text { Lightweight } \\
\text { Aggregate }\end{array}$ & Water & Additive \\
\hline & \multicolumn{8}{|c|}{$\mathrm{kg} / \mathrm{m}^{3}$} \\
\hline \multicolumn{9}{|l|}{ Beltrán et al. [19] } \\
\hline Control-1 & 300 & 0 & 0 & 819 & 1109 & - & 180 & 3 \\
\hline BBA-2-NG & 300 & 24.6 & 0 & 794 & 1109 & - & 183 & 3.9 \\
\hline BBA-3-NG & 300 & 49.2 & 0 & 770 & 1109 & - & 186 & 4.5 \\
\hline BBA-4-RCA & 300 & 0 & 985 & 868 & 0 & - & 228 & 3 \\
\hline BBA-35-RCA & 300 & 26 & 985 & 842 & 0 & - & 231 & 3.9 \\
\hline BBA-6-RCA & 300 & 52 & 985 & 816 & 0 & - & 234 & 4.5 \\
\hline BBA-7-MRA & 300 & 0 & 942 & 846 & 0 & - & 226 & 3 \\
\hline BBA-8-MRA & 300 & 26 & 942 & 820.5 & 0 & - & 229 & 3.9 \\
\hline BBA-9-MRA & 300 & 52 & 942 & 795 & 0 & - & 232 & 4.5 \\
\hline \multicolumn{9}{|l|}{ Lessard et al. [25] } \\
\hline Control-10-RCC & 300 & 0 & - & 931 & 1171 & - & 96 & 2.1 \\
\hline BBA-11-RCC & 296 & 373 & - & 375 & 1314 & - & 95 & 2.1 \\
\hline BBA-12-RCC & 296 & 615 & - & 0 & 1423 & - & 95 & 2.1 \\
\hline Control-13-PCC & 300 & 0 & - & 924 & 1186 & - & 111 & 2.1 \\
\hline BBA-14-PCC & 300 & 368 & - & 368 & 1275 & - & 111 & 2.1 \\
\hline BBA-15-PCC & 300 & 606 & - & 0 & 1381 & - & 111 & 2.1 \\
\hline \multicolumn{9}{|l|}{ Fontes et al. [27] } \\
\hline Control-16 & 393 & 0 & - & 668.1 & 1139.6 & - & 192.6 & 0 \\
\hline BBA-17 & 372.9 & 19.6 & - & 667.3 & 1138.3 & - & 192.3 & 0 \\
\hline BBA-18 & 352.8 & 39.2 & - & 666.5 & 1136.9 & - & 190.4 & 2.4 \\
\hline BBA-19 & 372.9 & 19.6 & - & 667.3 & 1138.3 & - & 191.7 & 0.9 \\
\hline BBA-20 & 352.8 & 39.2 & - & 666.5 & 1136.9 & - & 190.3 & 2.5 \\
\hline \multicolumn{9}{|l|}{ Rosales et al. [23] } \\
\hline Control-21 & 300 & 0 & 0 & 710.3 & 494.2 & 108.7 & 180 & 2.8 \\
\hline BBA-22 & 300 & 163.3 & 0 & 497.2 & 494.2 & 109.7 & 180 & 3.3 \\
\hline BBA-23-MRA & 300 & 163.3 & 217.8 & 498.2 & 247.1 & 110.7 & 180 & 3.3 \\
\hline BBA-24-MRA & 300 & 163.3 & 435.5 & 499.2 & 0 & 111.7 & 180 & 4 \\
\hline BBA-25-MRA & 300 & 86.1 & 321.9 & 609.5 & 247.1 & 72.5 & 180 & 3.4 \\
\hline BBA-26-MRA & 300 & 292.3 & 321.9 & 497.2 & 247.1 & 54.4 & 180 & 3.9 \\
\hline
\end{tabular}

The Bolomey method was used by Beltrán et al. [19] to determine the mix proportions. Nine batches were produced with three types of aggregates (natural aggregates, mixed recycled aggregates, and recycled concrete aggregates) and three percentages of replacement of natural sand by BBA $(0 \%, 3 \%$, and $6 \%)$. The amount of cement $\left(300 \mathrm{~kg} / \mathrm{m}^{3}\right)$, the water-cement relation $(\mathrm{w} / \mathrm{c}$ ratio 0.6$)$, and the slump (80-90 $\mathrm{mm}$ ) were constant for all the mixes manufactured. The total water shown in Table 4 corresponds to the sum of the water determined by the $\mathrm{w} / \mathrm{c}$ ratio plus the water required for saturation of RA and BBA.

Three RCC and three PCC mixes were made by Lessard et al. [25] with BBA as replacement of natural sand in different percentages $(0 \%, 50 \%$, and $100 \%)$. The mix proportions were made according to the maximum density curve equation developed by Fuller and Thompson. This method achieves a continuous particle size distribution that reduces the number of voids and increases the compactness of the mixes, which is a fundamental parameter in roller-compacted and pavement-compacted concrete. The amount of cement, $300 \mathrm{~kg} / \mathrm{m}^{3}$, was kept constant but with slight variations due to the Fuller-Thompson equation. A water cement ratio (w/c) of 0.32 for RCC and 0.37 for PCC were used to maintain a slump of 25 and 45s respectively, measured in Vede time (VBTs).

Five concrete mixes were made by Fontes et al. [27] with two types of BBA (as received and milling) and two cement replacements (5\% and 10\%). The water-binder (cement + BBA) ratio (w/b ratio $0.49)$ and the slump $(180 \pm 20 \mathrm{~mm})$ was the same in all mixes manufactured.

Six batches of lightweight concrete were made by Rosales et al. [23] in two series applying the Bolomey method to calculate the mix proportions. In series one, a substitution of $30 \%$ of natural sand by BBA was kept constant and replacement of natural coarse aggregate by MRA was varying. In series 
two, natural aggregates and lightweight aggregates was replaced by BBA in two percentages $(15 \%$ and $55 \%)$ and MRA, according to the particle size. The amount of cement $\left(300 \mathrm{~kg} / \mathrm{m}^{3}\right)$, the water-cement ratio (w/c ratio 0.6$)$, and the slump $(85 \pm 5 \mathrm{~mm})$ were constant in all the mixes.

\subsection{Fresh, Physical, Mechanical, and Durability Properties of Concrete Made from BBA}

This section presents the experimental evidence and results obtained by the different authors. Fresh concrete properties, physical and mechanical properties of hardened concrete and durability properties are shown as follows:

Table 5 shows the standards used by the authors to determinate each property.

Table 5. Different standards used by author to determinate each property.

\begin{tabular}{cccccc}
\hline Author/Standard Used & Workability & Compressive Strength & Flexural Strength & $\begin{array}{c}\text { Splitting Strength } \\
\text { Water Absorption } \\
\text { /Density }\end{array}$ \\
\hline Beltrán et al. [19] & EN 12350-2:2009 [44] & EN 12390-3:2009 [45] & EN 12390-5:2009 [46] & - & EN 12390-7:2009 [47] \\
Lessard et al. [25] & EN 12350-2:2009 [44] & ASTM C39/C39M-14 [48] & ASTM C78/C78M-10 [49] & - & ASTM C642-13 [50] \\
Fontes et al. [27] & ABNT NBR NM & ABNT NBR 5739 [52] & - & ABNT NBR 7222 [53] & ASTM C642-13 [50] \\
Rosales et al. [23] & EN 12350-2:2009 [44] & EN 12390-3:2009 [45] & EN 12390-5:2009 [46] & - & EN 12390-7:2009 [47] \\
\hline
\end{tabular}

\subsubsection{Workability}

As shown in Table 6, the workability was kept practically constant in concretes with a w/c ratio greater than 0.49 , due to the use of super plasticizing agents. However, in the RCC and PCC, due to their low $w / c$ ratio, linear workability losses were observed with the increase in BBA content, exceeding the recommended limits according to previous studies [54] for dry cast concrete.

\subsubsection{Water Absorption and Density}

Analyzing the density values shown in Table 6 by the different authors, it can be observed that the substitution of natural sand for BBA does not significantly affect the densities of the concretes, decreasing the density by $3 \%$ with a $6 \%$ substitution in nonstructural concretes. In RCC and PCC, where the compactness is greater than other types of concrete, an even lesser influence is observed, registering a $5 \%$ drop decrease in density with a 100\% substitution of NS by BBA.

It is also appreciated that the greatest decrease in density is associated with the combination of BBA with MRA as substitutes for natural sand and coarse aggregate, which allowed Rosales et al. [23] to manufacture lightweight concrete by replacement until $50 \%$ of lightweight aggregates while the same density values are maintained.

According to the results of Fontes et al. [27], the substitution of OCP by BBA does not affect the density of the samples.

Relative to water absorption, there is an increase in water absorption for all natural sand substitutions with an increase in the amount of BBA, due to the greater absorption of BBA particles and the greater porosity of the concrete manufactured with BBA. The use of ashes in concrete generally results in increased porosity of the specimens [55]. On the contrary, it is verified that the substitution of OPC by BBA implies an increase in water absorption, due to the low hydraulic reactivity of the ash used and the absorption of the BBA.

\subsubsection{Compressive, Flexural and Splitting strength}

For all the samples analyzed by the different authors, the incorporation of BBA in concrete manufacture implies a worse mechanical behavior than reference control samples without BBA. This decrease in the values of compressive, flexural, and tensile strength varies depending on the type of concrete manufactured, aggregates used, and type of BBA replacement (cement or natural sand).

As shown in Figure 4, there is no proportionality between the decrease in compressive strength and the amount of BBA incorporated, with drops ranging from $15 \%$ strength for $3 \%$ replacements in nonstructural concrete to $31 \%$ with $100 \%$ sand replacement by BBA in RCC. The high drop in 
compressive strength values in RCC is probably due to the lower $\mathrm{w} / \mathrm{c}$ ratio and the higher absorption of the BBA than NS, which decrease the compactness of the samples reducing their mechanical behavior, in addition to the reduction of the pozzolanicity of the biomass ashes with respect to the cement. Although BBA has hydraulic properties, it cannot be assimilated to cement, which leads to a reduction of strength in concrete. Similar behavior is observed in flexural strength (Table 6), which shows lower values in RCC samples than in PCC.

In contrast, the samples of lightweight concrete made with 30\% BBA show a drop of $11 \%$ for compressive strength and 3\% in flexural strength values, likely due to the higher $\mathrm{w} / \mathrm{c}$ ratio and the lower influence of the compactness on this type of concrete.

Finally, the drop in compressive and flexural strength values shown in concrete manufactured by Fontes el al. [27] is due to the substitution of a hydraulic binder for a material without pozzolanic properties.

Table 6. Mechanical properties of concrete mixes by authors.

\begin{tabular}{|c|c|c|c|c|c|c|c|}
\hline \multirow{2}{*}{ Mixes } & \multirow{2}{*}{$\begin{array}{l}\text { Workability } \\
(\mathrm{mm})\end{array}$} & \multicolumn{3}{|c|}{ Compressive Strength (MPa) } & \multirow{2}{*}{$\begin{array}{c}\begin{array}{c}\text { Flexural } \\
\text { Strength } \\
(\mathrm{MPa})\end{array} \\
28 \text { days }\end{array}$} & \multirow{2}{*}{$\begin{array}{l}\text { Absorption } \\
(\%)\end{array}$} & \multirow{2}{*}{$\begin{array}{l}\text { Density } \\
\left(\mathrm{g} / \mathrm{cm}^{3}\right)\end{array}$} \\
\hline & & 7 days & 28 days & 90 days & & & \\
\hline \multicolumn{8}{|l|}{ Beltrán et al. [19] } \\
\hline Control-1 & 90 & 29.8 & 44.3 & 48.5 & 5.9 & 5.7 & 2.36 \\
\hline BBA-2-NG & 80 & 29.6 & 37.7 & 42.2 & 4.9 & 5.9 & 2.34 \\
\hline BBA-3-NG & 80 & 27.5 & 35.4 & 39.8 & 4.7 & 6.3 & 2.33 \\
\hline BBA-4-RCA & 90 & 26.5 & 35.9 & 40.8 & 4.9 & 6.5 & 2.18 \\
\hline BBA-5-RCA & 80 & 24.5 & 33.3 & 39.7 & 4.6 & 6.9 & 2.18 \\
\hline BBA-6-RCA & 75 & 22.8 & 30.1 & 34.2 & 4.5 & 7.6 & 2.17 \\
\hline BBA-7-MRA & 80 & 22.9 & 32 & 37.3 & 4.4 & 6.7 & 2.10 \\
\hline BBA-8-MRA & 85 & 22.2 & 30.4 & 34.9 & 4.3 & 7.2 & 2.14 \\
\hline BBA-9-MRA & 80 & 21.7 & 27.7 & 30.5 & 4.1 & 7.7 & 2.14 \\
\hline Lessard et al. [25] & $\begin{array}{l}\text { Vee-Bee Test } \\
\text { VBT (s) }\end{array}$ & & & & & & \\
\hline Control-10-RCC & 37 & 38 & 42 & 49 & 8.3 & - & 2.39 \\
\hline BBA-11-RCC & 57 & 31.5 & 35 & 40 & 5.6 & - & 2.36 \\
\hline BBA-12-RCC & 70 & 25 & 29 & 30.5 & 4.8 & - & 2.33 \\
\hline Control-13-PCC & 25 & 39 & 47.5 & 52 & 7.5 & 3.8 & 2.46 \\
\hline BBA-14-PCC & 37 & 32 & 38 & 39.5 & 7.2 & 4.9 & 2.41 \\
\hline BBA-15-PCC & 60 & 33.5 & 41 & 43.5 & 6.9 & 6.1 & 2.38 \\
\hline Fontes et al. [27] & $(\mathrm{mm})$ & & & $\begin{array}{c}\text { (365 } \\
\text { days) }\end{array}$ & & & \\
\hline Control-16 & $180 \pm 20$ & 22.3 & 33.7 & 40 & $\begin{array}{c}2.53 \\
\text { (Splitting) }\end{array}$ & 5.1 & 2.40 \\
\hline BBA-17 & $180 \pm 20$ & 24.3 & 27.8 & 33.8 & $\begin{array}{c}2.14 \\
\text { (Splitting) }\end{array}$ & 4.8 & 2.40 \\
\hline BBA-18 & $180 \pm 20$ & 23.2 & 25.6 & - & $\begin{array}{c}2.02 \\
\text { (Splitting) }\end{array}$ & 4.4 & 2.40 \\
\hline BBA-19 & $180 \pm 20$ & 22.6 & 25.3 & - & $\begin{array}{c}2.37 \\
\text { (Splitting) }\end{array}$ & 4.4 & 2.40 \\
\hline BBA-20 & $180 \pm 20$ & 22.7 & 27.3 & - & $\begin{array}{c}1.89 \\
\text { (Splitting) }\end{array}$ & 4.5 & 2.40 \\
\hline Rosales et al. [23] & $(\mathrm{mm})$ & & & & & & \\
\hline Control-21 & 80 & 25.9 & 31.6 & 37.6 & 4.4 & 8.8 & 1.80 \\
\hline BBA-22 & 85 & 20.4 & 28 & 33.9 & 4.2 & 9.7 & 1.69 \\
\hline BBA-23-MRA & 85 & 19.6 & 26.7 & 32.5 & 4.1 & 11.1 & 1.64 \\
\hline BBA-24-MRA & 80 & 18.7 & 21.3 & 26.1 & 3.8 & 12.7 & 1.57 \\
\hline BBA-25-MRA & 80 & 19.8 & 27.1 & 33.2 & 4.2 & 10.9 & 1.79 \\
\hline BBA-26-MRA & 90 & 16.3 & 20.4 & 22.3 & 3.8 & 12.3 & 1.81 \\
\hline
\end{tabular}




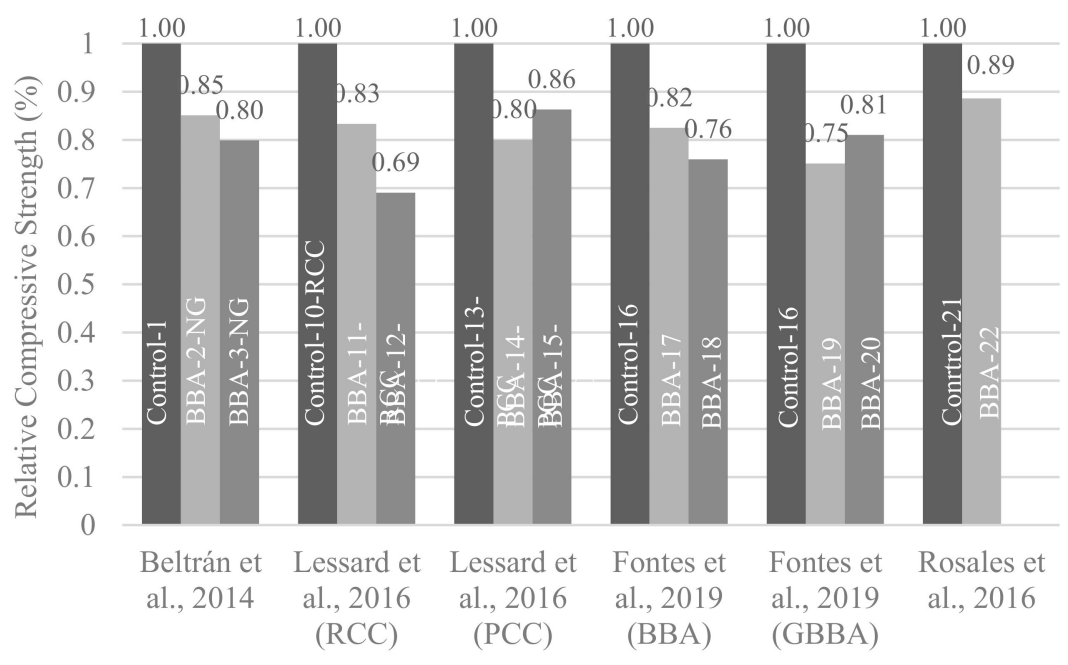

Figure 4. Comparison of compressive strength at 28 days with respect to reference concrete by authors $[19,23,25,27]$.

\subsubsection{Durability Properties}

To measure the durability of recycled concrete made from BBA, the authors analyzed in this work applied different standards or experimental tests.

Beltrán et al. [19] and Rosales et al. [23] studied the durability of concrete through the penetration of water under pressure test, according to EN 12390-8 [56], and the drying shrinkage measurements, according to ASTC C157 [57]. Table 7 shows the results obtained by the authors.

Table 7. Durability properties of hardened concrete.

\begin{tabular}{ccc}
\hline Mixes & Water Penetration at 28 Days $(\mathbf{m m})$ & Shrinkage at 90 Days $(\mu \mathrm{m} / \mathbf{m})$ \\
\hline Beltrán et al. [19] & & \\
\hline Control-1 & 36.6 & 276 \\
BBA-2-NG & 61.5 & 446 \\
BBA-3-NG & 75.3 & 479 \\
BBA-4-RCA & 65.5 & 381 \\
BBA-35-RCA & 79.3 & 439 \\
BBA-6-RCA & 102.6 & 471 \\
BBA-7-MRA & 70.7 & 445 \\
BBA-8-MRA & 86.7 & 500 \\
BBA-9-MRA & 112.6 & 510 \\
Rosales et al. [23] & & \\
\hline Control-21 & 65.7 & 434 \\
BBA-22 & 70.5 & 448 \\
BBA-23-MRA & 77.9 & 485 \\
BBA-24-MRA & 84.6 & 524 \\
BBA-25-MRA & 75.6 & 467 \\
BBA-26-MRA & 82.4 & 531 \\
\hline
\end{tabular}

Water penetration under pressure was measured at 28 days and the negative effect of BBA incorporation is observed in all samples. However, this increase was more pronounced in conventional nonstructural concrete, with increases of $69 \%$ and $110 \%$ for substitutions of $3 \%$ and $6 \%$, respectively, compared to the $7 \%$ increase for a BBA replacement of $30 \%$ in lightweight concrete, likely, due to the higher porosity of reference lightweight concrete made with lightweight aggregates.

The dry shrinkage measurements indicate that the concrete with higher BBA replacement have higher shrinkage values, negatively affecting durability. 
The permeability of PCC samples was measured by Lessard et al. [25] through electrical resistivity at 28 and 90 days. According to the results obtained, all the samples showed low values of electrical resistivity between 89 and $146 \mathrm{k} \Omega . \mathrm{cm}$, therefore, the permeability was also very low, indicating that the concrete has a low potential of ion-chloride penetration or other corrosive agents.

The stiffness damage test (SDT) was carried out by Fontes et al. [27] in order to analyze the possible expansive reactions caused by the alkali-silica components present in the BBA, which generate micro-cracking in the concrete, reducing the mechanical properties.

The SDT was carried out applying compression load cycles, in order to obtain the load-discharge curve for each concrete, since the analysis of surface area of hysteresis loops is related to the potential alkali-silica reaction damage.

The stress-deformation relationship did not show a significant increase in the hysteresis area of the BBA5 sample compared to the REF sample, indicating that there were no expansive reactions after 365 days.

\subsection{Discussion}

Despite the fact that BBA is a heterogeneous material with properties that depend on the type of biomass and combustion process, it has certain common characteristics, such as low density, high absorption of particles, and a rough and porous appearance, which give concrete with natural sand substitutions for BBA similar characteristics, such as decreased in workability and slight decrease in density, greater absorption of water and porosity, decrease in mechanical behavior, such as compressive, flexural, and tensile strengths and modification of durability properties, but which vary depending on the type of concrete manufactured and the dosage.

On the contrary, for BBA substitutions for cement, the physical properties such as water absorption and porosity are due to a possible refinement of the concrete structure.

RCC and PCC are the typologies most affected by the substitution of NS by BBA, due to the low $\mathrm{w} / \mathrm{c}$ ratio and the high absorption of BBA, which implies a reduction in workability outside the limits, in addition to the disorder in the particle-size distribution caused by BBA negatively affecting compactness, which is a determining parameter in this type of concrete, reducing mechanical behavior.

In contrast, lightweight concrete shows a better adaptation to the substitution of natural aggregate and lightweight aggregate for BBA, due to the similarities between expanded clay and BBA.

Although there is a reduction in mechanical properties and durability, it is within the limits for the execution of lightweight structural concrete, also ensuring the necessary density values.

\section{Biomass Bottom Ash in CTGM (Soil Cement) and Soil Stabilization}

Cement-treated granular materials (CTGM) or also called cement soil, are homogeneously compacted mixes of soil or granular materials, cement and water, widely used in structural pavement layers [58].

In the last decade, many studies have been carried out on the use of CTGM incorporating industrial by-products. The most used waste has been recycled aggregate from construction and demolition waste. Xuan et al. [59] reported on the properties of CTGM manufactured with recycled aggregate and different percentages of cement, while Perez et al. [60] carried out research based on a real application in road base construction, using recycled aggregates of different composition such as CTGM.

The incorporation of other industrial by-products such as steel slag, ash from power plants, blast furnaces as raw material for the manufacture of CTGM or to stabilize marginal soils are being studied. Sarkkinen et al. [61] used biomass fly ash as a binder for road stabilization.

However, there are very few studies in which BBA is used as CTGM or for soil stabilization. Cabrera et al. [20], studied the possibility of using BBA as a raw material mixed with natural aggregates and recycled aggregates as a road base or sub-base. They reported physical, chemical, and mechanical parameters with very satisfactory results in some of the dosages used. In 2018, Cabrera et al. [24] presented an experimental investigation of stabilization of expansive soils by removing lime and 
incorporating BBA. The results showed significant improvements in the mechanical behavior of the studied mixes.

\subsection{Dosages}

A total of 15 mixes were manufactured by the different authors analyzed. The proportions are summarized in Table 8, indicating the percentage by weight of each material that makes up the mix.

Cabrera et al. [24] made five mixes of stabilized soil. Four of them with different percentages of BBA added $(0 \%, 15 \%, 50 \%$, and $100 \%)$ and a mix with a replacement of $5 \%$ of expanded clay soil (ECS) by quicklime, in order to establish a reference mix.

Six mixes were produced by Cabrera et al. [20] varying the percentage of BBA replacement $(0 \%, 15 \%$, and $30 \%$ ) and the percentage of cement added: $3 \%$ in series one (S1) and $5 \%$ in the second series (S2).

Finally, due to the lack of development of cement-treatment granular materials with BBA, four mixes made by Sarkkinen et al. [61] varying the binder/soil ratio and the proportions between cement and BFA used in the binder composition were analyzed, in order to be compared with the results obtained by Cabrera et al. [20]

BFA used by Sarkikinen et al. [61] which come from the combustion of wood biomass in an energy plant in Finland, present higher $\mathrm{CaO}$ values indicating a possible greater strength development of treatment materials due to the potential hydraulic reactions which is consistent with other studies conducted with BFA from wood biomass [62].

Table 8. Proportions of mixes design by authors.

\begin{tabular}{|c|c|c|c|c|c|c|c|}
\hline Mixes & $\begin{array}{l}\text { ECS } \\
\text { wt. \% }\end{array}$ & Quicklime (QL) & BBA & NA & BFA & OPC & Soil \\
\hline \multicolumn{8}{|c|}{ Cabrera et al. [24] } \\
\hline ECS-1 & 100 & & & & & & \\
\hline BBA-2 & & & 100 & & & & \\
\hline $\mathrm{ECS}+\mathrm{BBA}-3$ & 50 & & 50 & & & & \\
\hline $\mathrm{ECS}+\mathrm{BBA}-4$ & 85 & & 15 & & & & \\
\hline $\mathrm{ECS}+\mathrm{QL}-5$ & 95 & 5 & & & & & \\
\hline \multicolumn{8}{|c|}{ Cabrera et al. [20] } \\
\hline Control-6 & & & 0 & 97 & & 3 & \\
\hline BBA-7-NA & & & 15 & 82 & & 3 & \\
\hline BBA-8-NA & & & 30 & 67 & & 3 & \\
\hline MRA-9 & & & 0 & 95 & & 5 & \\
\hline BBA-10-MRA & & & 15 & 80 & & 5 & \\
\hline BBA-11-MRA & & & 30 & 65 & & 5 & \\
\hline \multicolumn{8}{|c|}{ Sarkkinen et al. [61] } \\
\hline BFA-12 & & & & & 14 & 3 & 83 \\
\hline BFA-13 & & & & & 13 & 3 & 83 \\
\hline BFA-14 & & & & & 21 & 3 & 75 \\
\hline BFA-15 & & & & & 8 & 4 & 88 \\
\hline
\end{tabular}

\subsection{Experimental Methods and Results}

This section shows the results of the laboratory tests carried out by each author on the stabilized soil with BBA, cement treatment granular material with BBA, and cement treatment granular soil with BFA in order to analyze the effect of the BBA in soil and natural aggregates with and without cement and establish a comparison between the BBA and BFA effects on mechanical properties of CTGM.

Cabrera et al. [20,24] performed the moisture-density test, according to EN 103 501-94 [63] (Proctor Modified Test), in order to obtain the optimal moisture content to ensure the maximum dry density. Once the optimal moisture content and maximum dry density value had been obtained, all samples were compacted using a vibrating hammer in a cylindrical mold, filling in three layers. The compressive strength was measured according to NLT-305-90 [64]. 
Sarkkinen et al. [61] made the mixes according to EN 12390-1 [65], filling cube molds which were compacted using a vibrating table. The water content was varied and adapted so all the samples could be made applying that method. The compressive strength was measured according to EN 12390-3 [45].

Table 9 shows the density of all samples analyzed and the compressive strength of cement treatment materials.

Table 9. Compressive strength and density of all mixes by authors.

\begin{tabular}{|c|c|c|c|c|}
\hline \multirow{2}{*}{ Mixes } & \multicolumn{2}{|c|}{ Compressive Strength (MPa) } & \multirow{2}{*}{ Density $\left(\mathrm{g} / \mathrm{cm}^{3}\right)$} & \multirow{2}{*}{ BBA $(\%)$} \\
\hline & 7 Days & 28 Days & & \\
\hline \multicolumn{5}{|c|}{ Cabrera et al. [24] } \\
\hline ECS-1 & - & - & 1.69 & 0 \\
\hline BBA-2 & - & - & 1.33 & 100 \\
\hline $\mathrm{ECS}+\mathrm{BBA}-3$ & - & - & 1.53 & 50 \\
\hline $\mathrm{ECS}+\mathrm{BBA}-4$ & - & - & 1.58 & 15 \\
\hline ECS+QL-5 & - & - & 1.56 & 0 \\
\hline \multicolumn{5}{|c|}{ Cabrera et al. [20] } \\
\hline Control-6 & 1.86 & 2.31 & 2.23 & 0 \\
\hline BBA-7-NA & 2.67 & 4.3 & 1.92 & 15 \\
\hline BBA-8-NA & 2.52 & 3.26 & 1.77 & 30 \\
\hline MRA-9 & 2.52 & 3.55 & 2.26 & 0 \\
\hline BBA-10-MRA & 4.12 & 6.47 & 1.95 & 15 \\
\hline BBA-11-MRA & 3.52 & 4.48 & 1.79 & 30 \\
\hline \multicolumn{5}{|c|}{ Sarkkinen et al. [61] } \\
\hline BFA-12 & 3.8 & 5.2 & 2.16 & 14 \\
\hline BFA-13 & 3 & 5.3 & 2.2 & 13 \\
\hline BFA-14 & 3.9 & 8.7 & 2.06 & 21 \\
\hline BFA-15 & 2.5 & 5 & 2.09 & 8 \\
\hline
\end{tabular}

Density values are related to the compaction of the samples, so under optimal conditions of moisture and compactness CTGM with BBA made by Cabrera et al. [20] present lower density values than the reference samples, likely due to the lower density of BBA which reduces the total content of cement in a meter cubic of mix. However, no relationship was observed between BBA content and density in the mix made by Sarkinnen et al. [61], because the compactness conditions were not optimal.

In addition, stabilized soil with BBA has no significant variances present in density values compared to the reference value obtained in the sample stabilized with quicklime.

Analyzing the compressive strength values, the soil treated samples made by Sarkkinen et al. [61] show a reduction in strength properties with the increase in BBA caused by the uncontrolled compactness and moisture conditions; however, the incorporation of BBA together with cement had positive effects indicating the potential to manufacture binder from BFA.

On the contrary, the samples manufactured by Cabrera el al. [20] show a significant improvement in strength properties due to the incorporation of BBA in both series, with increases of $25 \%$ on average between 7 and 28 days.

In addition, analyzing the stress-strain relationship obtained from strength test which were carried out on the mixes, the modulus of elasticity was determined. The elastic properties of a cement-treated soil allow estimating the bearing capacity of a pavement since higher elastic modulus implies a better traffic load distribution, generating less distortion which guarantees an adequate structural behavior of the road over its lifetime.

Figure 5 shows the results of compressive strength and modulus of elasticity obtained by Cabrera et al. [20]. 


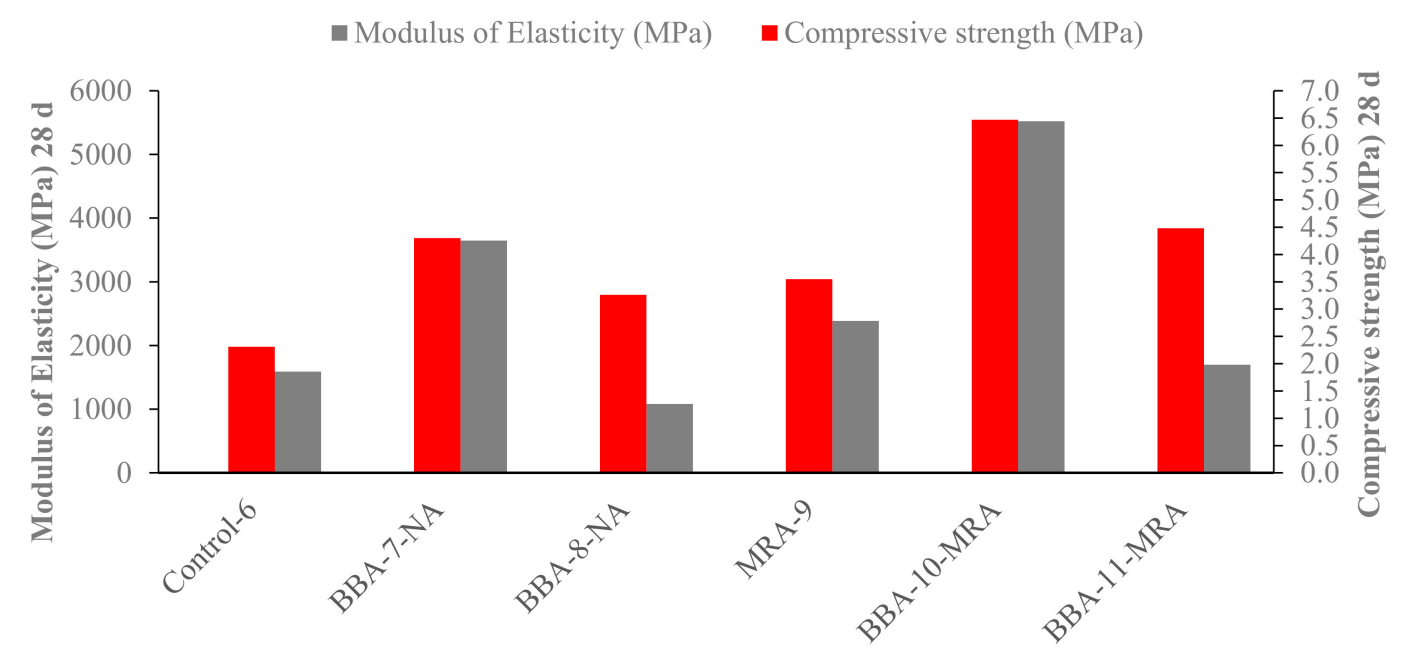

Figure 5. Comparative between compressive strength and modulus of elasticity. (Modified from Cabrera et al. [20]).

According to the results, a similar effect was observed in both series. For an incorporation of $15 \%$ of BBA, the compressive strength and the modulus of elasticity improved compared to the reference samples, although the mixes made with a percentage of BBA of $30 \%$ presented similar values of compressive strength and worse results in modulus of elasticity.

Finally, stabilized soil with BBA has no compressive strength value, since the mixes do not have any cement content, so the bearing capacity was measured by the CBR test, according to EN 103 502-95 [66]. The results of the CBR index under soak and un-soak conditions are shown in Figure 6, and as observed, the bearing capacity of samples which were made with BBA were better than the soil stabilized with lime, probably due to the high $\mathrm{CaO}$ content which reduces plasticity and free swelling, improving the mechanical behavior of the soil.

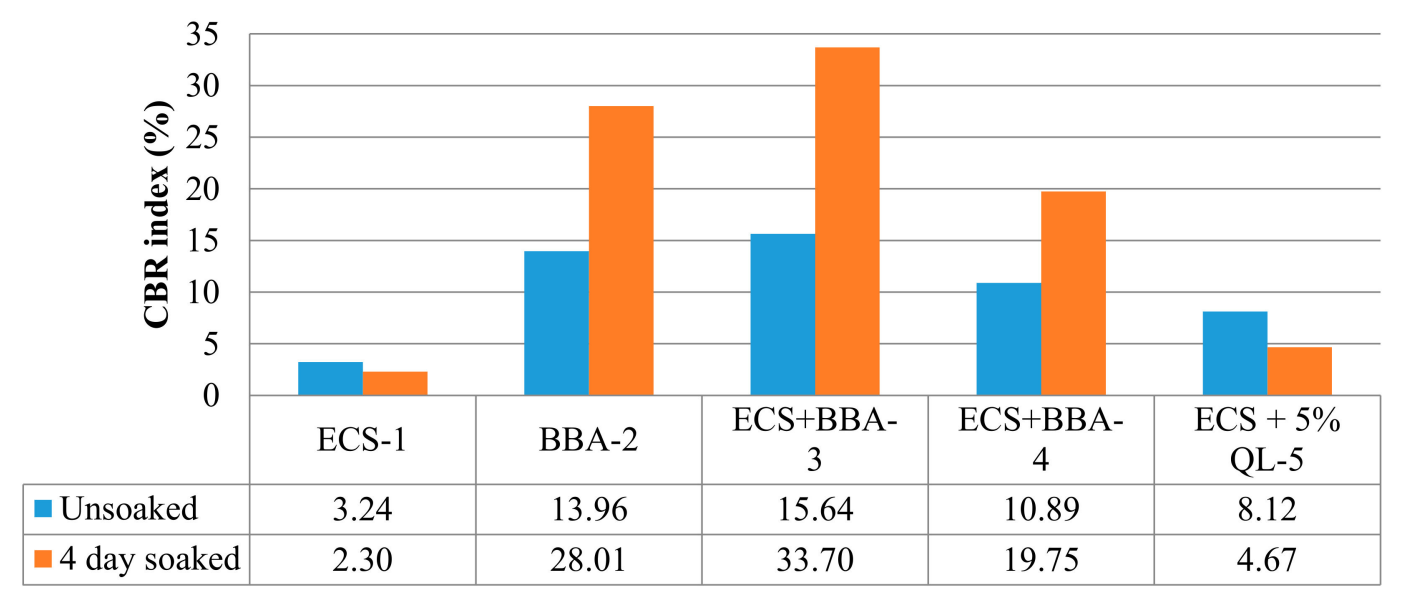

Figure 6. CBR values of stabilized soil. (Plotted from Cabrera et al. [24]).

\subsection{Discussion}

The physicochemical properties of BBA and BFA condition the mechanical behavior of stabilized soils and cement-treated soils.

The stabilizing potential of ash with a high $\mathrm{CaO}$ percentage, generally over $20 \%$, has been observed, which is consistent with previous studies [40], reducing free swelling and soil plasticity, thus improving its load-bearing capacity, as indicated by the positive results obtained by Cabrera et al. [24]. 
The pozzolanic activity of biomass ash is known to depend on $\mathrm{Si}+\mathrm{Fe}+\mathrm{Al}$ and $\mathrm{CaO}$ content, but also on other factors such as the specific surface area, organic matter content, and crystalline structure of the phases, for which BFA generally have been considered more reactive than BBA. Sarkkinen et al. [61] showed that the use of BFA with high contents of $\mathrm{Si}+\mathrm{Fe}+\mathrm{Al}$ (50-70\%) mixed with cement improves the properties of the binder, on the contrary, no positive results were obtained regarding the development of compressive strength.

However, Cabrera et al. [20] obtained very positive results with incorporation of 15\% BBA together with incorporation of $3 \%$ and $5 \%$ cement, with increases in the compressive strength and modulus of elasticity of the samples tested, which implies that the use of BBA with a lower theoretical potential of pozzolanic reactivity can improve the mechanical behavior of the soil under optimal compaction and moisture conditions.

\section{Conclusions}

Based on the literature reviewed in this work, the feasibility of using BBA from different origins and with different treatments has been analyzed for application in cement-based materials such as mortars, concrete, or CTGM. It has been demonstrated that the characteristics of materials manufactured with BBA have improved and worsened, due to the variability in the properties of the ash and the different processes of manufacture used by each author.

The following conclusions are obtained from the analysis of the literature:

(1) The results from mortar manufactured with BBA indicate that:

The main components of the $\mathrm{BBA}$ are $\mathrm{SiO} 2$ and $\mathrm{CaO}$, these values are appropriate to produce pozzolanic reactions and have a positive cementitious capacity.

The use of BBA in the manufacture of mortar increases porosity, as a consequence of porosity, decreases density and lowers mechanical strength. The different studies agree that the negative effect on mechanical properties is due to the content of organic matter present in BBA.

(2) The results from concrete manufactured with BBA indicate that:

Previous research reports that concrete made with BBA present worse mechanical behavior than control samples, although the values are enough to ensure the minimum requirements established by the different standards.

Concrete with lower water to binder ratio are the type most affected by the BBA incorporation, due to the high water absorption which reduces the workability and decrease the mechanical behavior.

BBA with high alkali elements contents such as $\mathrm{K} 2 \mathrm{O}$ has no negative effects on the durability properties of concrete.

(3) The results of the cement treatment granular material manufactured with BBA indicate that:

BBA with high $\mathrm{CaO}$ contents has stabilizing properties to use in expansive soils, improving the bearing capacity of the soils.

$\mathrm{BBA}$ with high $\mathrm{Si}+\mathrm{Fe}+\mathrm{Al}$ and $\mathrm{CaO}$ content with cement improve the mechanical behavior of the treated soil.

The compaction process and moisture content determine the development of compressive strength of soils treated with BBA.

The real possibility of using BBA in cement-based materials for its application in civil engineering has been demonstrated, promoting a circular economy model in which waste from the generation of energy from biomass is used reducing or eliminating its deposit in landfills.

\section{Future Research Lines}

After analyzing the current state of development of cement-based materials manufactured with BBA, some aspects of future research are listed below: 
To study the physical-chemical properties of different BBAs produced in different treatment plants. The influence of the origin of the material and the combustion system on the final properties acquired by the waste will be identified. In this way, a relationship will be sought between the source material, combustion system, BBA properties, and the most appropriate use for them.

Mechanical behavior comparative study of cement-based materials manufactured with different BBA typologies, and long-term (12-24 months) durability analysis.

Long-term microscopy studies (12-24 months) to analyze the evolution of the internal structure of cement-based materials manufactured with BBA.

Author Contributions: Conceptualization, M.C. and J.L.D.-L.; methodology, J.R. and F.A.; investigation, M.C. and J.R.; resources, F.A. and J.L.D.-L.; data curation, J.L.D.-L. and M.C.; writing-original draft preparation, M.C. and J.L.D.-L.; writing-review and editing, M.C., J.R. and J.L.D.-L.; supervision, F.A.; All authors have read and agreed to the published version of the manuscript.

Funding: This work has been partially financed by the project "Assessment of biomass bottom ash for sustainable construction applications-BIOCEM", granted by the call for "R \& D \& I projects within the framework of the ERDF Andalusia 2014-2020 Operational Program-UCO-FEDER, 2018" funded by the Direction of Economy, Knowledge, Business and University, of the Junta de Andalucía.

Conflicts of Interest: The authors declare no conflict of interest.

\section{References}

1. Demirbas, M.F.; Balat, M.; Balat, H. Potential contribution of biomass to the sustainable energy development. Energy Convers. Manag. 2009, 50, 1746-1760. [CrossRef]

2. Capros, P.; Mantzos, L.; Tasios, N.; De Vita, A.; Kouvaritakis, N. EU Energy Trends to 2030: Update 2009; Publications Office of the European Union: Luxembourg, 2010; p. 9279161911.

3. Babich, I.; Van Der Hulst, M.; Lefferts, L.; Moulijn, J.; O'Connor, P.; Seshan, K. Catalytic pyrolysis of microalgae to high-quality liquid bio-fuels. Biomass Bioenergy 2011, 35, 3199-3207. [CrossRef]

4. Li, D.; Chen, L.; Zhang, X.; Ye, N.; Xing, F. Pyrolytic characteristics and kinetic studies of three kinds of red algae. Biomass Bioenergy 2011, 35, 1765-1772. [CrossRef]

5. Besel, S.A. Biomass: Gasification; Energy (IDEA); Institute for the Diversification and Saving of S. S.: Madrid, Spain, 2007; pp. 1-36.

6. Modolo, R.C.E.; Ferreira, V.; Tarelho, L.; Labrincha, J.; Senff, L.; Silva, L. Mortar formulations with bottom ash from biomass combustion. Constr. Build. Mater. 2013, 45, 275-281. [CrossRef]

7. Cabrera, M.; Galvín, A.P.; Agrela, F.; Carvajal, M.D.; Ayuso, J. Characterisation and technical feasibility of using biomass bottom ash for civil infrastructures. Constr. Build. Mater. 2014, 58, 234-244. [CrossRef]

8. CEDEX, C.d.E.y.E.d.O.P. Cenizas Procedentes de la Incineración de Biomasa. Available online: http://www. cedexmateriales.es/catalogo-de-residuos/23/cenizas-procedentes-de-laincineracion-de-biomasa/ (accessed on 1 December 2014).

9. Koppejan, J.; Van Loo, S. The Handbook of Biomass Combustion and Co-Firing; Routledge: London, UK, 2012; p. 1136553770.

10. Yusta, M.C.; Mármol, I.; Morales, J.; Sánchez, L. Use of olive biomass fly ash in the preparation of environmentally friendly mortars. Environ. Sci. Technol. 2011, 45, 6991-6996. [CrossRef]

11. Maschio, S.; Tonello, G.; Piani, L.; Furlani, E. Fly and bottom ashes from biomass combustion as cement replacing components in mortars production: Rheological behaviour of the pastes and materials compression strength. Chemosphere 2011, 85, 666-671. [CrossRef]

12. Tosti, L.; Van Zomeren, A.; Pels, J.R.; Comans, R.N. Technical and environmental performance of lower carbon footprint cement mortars containing biomass fly ash as a secondary cementitious material. Resour. Conserv. Recycl. 2018, 134, 25-33. [CrossRef]

13. Wang, S. Cofired biomass fly ashes in mortar: Reduction of Alkali Silica Reaction (ASR) expansion, pore solution chemistry and the effects on compressive strength. Constr. Build. Mater. 2015, 82, 123-132. [CrossRef]

14. Teixeira, E.; Mateus, R.; Camões, A.; Branco, F. Quality and durability properties and life-cycle assessment of high volume biomass fly ash mortar. Constr. Build. Mater. 2019, 197, 195-207. [CrossRef]

15. Tkaczewska, E.; Mroz, R.; Łój, G. Coal-biomass fly ashes for cement production of CEM II/A-V 42.5R. Constr. Build. Mater. 2012, 28, 633-639. [CrossRef] 
16. Wang, S.; Llamazos, E.; Baxter, L.; Fonseca, F. Durability of biomass fly ash concrete: Freezing and thawing and rapid chloride permeability tests. Fuel 2008, 87, 359-364. [CrossRef]

17. Cuenca, J.; Rodriguez, J.; Martín-Morales, M.; Sánchez-Roldán, Z.; Zamorano, M. Effects of olive residue biomass fly ash as filler in self-compacting concrete. Constr. Build. Mater. 2013, 40, 702-709. [CrossRef]

18. Beltran, M.G.; Barbudo, A.; Agrela, F.; Jiménez, J.R.; De Brito, J. Mechanical performance of bedding mortars made with olive biomass bottom ash. Constr. Build. Mater. 2016, 112, 699-707. [CrossRef]

19. Beltrán, M.G.; Agrela, F.; Barbudo, A.; Ayuso, J.; Ramírez, A. Mechanical and durability properties of concretes manufactured with biomass bottom ash and recycled coarse aggregates. Constr. Build. Mater. 2014, 72, 231-238. [CrossRef]

20. Cabrera, M.; Agrela, F.; Ayuso, J.; Galvin, A.P.; Rosales, J. Feasible use of biomass bottom ash in the manufacture of cement treated recycled materials. Mater. Struct. 2016, 49, 3227-3238. [CrossRef]

21. Rosales, J.; Cabrera, M.; Beltrán, M.G.; López, M.; Agrela, F. Effects of treatments on biomass bottom ash applied to the manufacture of cement mortars. J. Clean. Prod. 2017, 154, 424-435. [CrossRef]

22. Hinojosa, M.; Galvín, A.P.; Agrela, F.; Perianes, M.; Barbudo, A. Potential use of biomass bottom ash as alternative construction material: Conflictive chemical parameters according to technical regulations. Fuel 2014, 128, 248-259. [CrossRef]

23. Rosales, J.; Beltrán, M.G.; Cabrera, M.; Velasco, A.; Agrela, F. Feasible use of biomass bottom ash as addition in the manufacture of lightweight recycled concrete. Waste Biomass Valorization 2016, 7, 953-963. [CrossRef]

24. Cabrera, M.; Rosales, J.; Ayuso, J.; Estaire, J.; Agrela, F. Feasibility of using olive biomass bottom ash in the sub-bases of roads and rural paths. Constr. Build. Mater. 2018, 181, 266-275. [CrossRef]

25. Lessard, J.M.; Omran, A.F.; Tagnit-Hamou, A.; Gagne, R.R.J. Feasibility of using biomass fly and bottom ashes to produce RCC and PCC. J. Mater. Civ. Eng. 2017, 29, 04016267. [CrossRef]

26. Lessard, J.M.; Omran, A.; Tagnit-Hamou, A.; Gagné, R. Feasibility of using biomass fly and bottom ashes in dry-cast concrete production. Constr. Build. Mater. 2017, 132, 565-577. [CrossRef]

27. Fontes, C.M.A.; Silva, R.B.; Lima, P.R.L. Characterization and effect of using bottom and fly ashes from co-combustion of cocoa waste as mineral addition in concrete. Waste Biomass Valorization 2019, 10, $223-233$. [CrossRef]

28. Medina, J.; Del Bosque, I.S.; Frías, M.; De Rojas, M.S.; Medina, C. Durability of new blended cements additioned with recycled biomass bottom ASH from electric power plants. Constr. Build. Mater. 2019, 225, 429-440. [CrossRef]

29. Sklivaniti, V.; Tsakiridis, P.; Katsiotis, N.; Velissariou, D.; Pistofidis, N.; Papageorgiou, D.; Beazi, M. Valorisation of woody biomass bottom ash in Portland cement: A characterization and hydration study. J. Environ. Chem. Eng. 2017, 5, 205-213. [CrossRef]

30. Carrasco, B.; Cruz, N.; Terrados-Cepeda, J.; Corpas, F.; Pérez-Villarejo, L. An evaluation of bottom ash from plant biomass as a replacement for cement in building blocks. Fuel 2014, 118, 272-280. [CrossRef]

31. Gemelli, E.; Cruz, A.A.D.F.; Camargo, N.H.A. A study of the application of residue from burned biomass in mortars. Mater. Res. 2004, 7, 545-556. [CrossRef]

32. Vassilev, S.V.; Baxter, D.; Andersen, L.K.; Vassileva, C.G. An overview of the composition and application of biomass ash. Part 1. Phase-mineral and chemical composition and classification. Fuel 2013, 105, 40-76. [CrossRef]

33. Agrela, F.; Cabrera, M.; Morales, M.M.; Zamorano, M.; Alshaaer, M. Biomass fly ash and biomass bottom ash. In New Trends in Eco-efficient and Recycled Concrete; Woodhead Publishing: Cambridge, UK; Elsevier: London, UK, 2019; pp. 23-58.

34. Segui, P.; Aubert, J.; Husson, B.; Measson, M. Characterization of wastepaper sludge ash for its valorization as a component of hydraulic binders. Appl. Clay Sci. 2012, 57, 79-85. [CrossRef]

35. Abraham, R.; George, J.; Thomas, J.; Yusuff, K. Physicochemical characterization and possible applications of the waste biomass ash from oleoresin industries of India. Fuel 2013, 109, 366-372. [CrossRef]

36. Umamaheswaran, K.; Batra, V.S. Physico-chemical characterisation of Indian biomass ashes. Fuel 2008, 87, 628-638. [CrossRef]

37. Huang, Y.; Mcllveen-Wright, D.; Rezvani, S.; Wang, Y.; Hewitt, N.J.; Williams, B. Biomass co-firing in a pressurized fluidized bed combustion (PFBC) combined cycle power plant: A techno-environmental assessment based on computational simulations. Fuel Process. Technol. 2006, 87, 927-934. [CrossRef] 
38. ASTM C270-19ae1. Standard Specification for Mortar for Unit Masonry; ASTM International: West Conshohocken, PA, USA, 2019.

39. ASTM C305-14. Standard Practice for Mechanical Mixing of Hydraulic Cement Pastes and Mortars of Plastic Consistency; ASTM International: West Conshohocken, PA, USA, 2014.

40. EN 1015-2:1999/A1:2007. Methods of Test for Mortar for Masonry_Part 2: Bulk Sampling of Mortars and Preparation of Test Mortars; European Committee for Standardization: Brussels, Belgium, 2007.

41. EN 196-1:2018. Methods of Testing Cement-Part 1: Determination of Strength; European Committee for Standardization: Brussels, Belgium, 2018.

42. EN 772-16:2011. Methods of Test for Masonry Units_Part 16: Determination of Dimensions; European Committee for Standardization: Brussels, Belgium, 2011.

43. EHE-08. Instrucción de Hormigón Estructural; Secretaría General Técnica, Ministerio de Fomento: Madrid, España, 2008. (In Spanish)

44. EN 12350-2:2009. Testing Fresh Concrete_Part 2: Slump-Test; European Committee for Standardization: Brussels, Belgium, 2009.

45. EN 12390-3:2009. Testing Hardened Concrete—Part 3: Compressive Strength of Test Specimens; European Committee for Standardization: Brussels, Belgium, 2009.

46. EN 12390-5:2009. Testing Hardened Concrete-Part 5: Flexural Strength of Test Specimens; European Committee for Standardization: Brussels, Belgium, 2009.

47. EN 12390-7:2009. Testing Hardened Concrete_Part 7: Density of Hardened Concrete; European Committee for Standardization: Brussels, Belgium, 2009.

48. ASTM C39/C39M-14. Standard Test Method for Compressive Strength of Cylindrical Concrete Specimens; ASTM International: West Conshohocken, PA, USA, 2014.

49. ASTM C78/C78M-10. Standard Test Method for Flexural Strength of Concrete (Using Simple Beam with Third-Point Loading); ASTM International: West Conshohocken, PA, USA, 2010.

50. ASTM C642-13. Standard Test Method for Density, Absorption, and Voids in Hardened Concrete; ASTM International: West Conshohocken, PA, USA, 2013.

51. ABNT NBR NM 67:1998. Concrete-Slump Test for Determination of the Consistency; Associação Brasileira de Normas Técnicas (ABNT): Rio de Janeiro, Brazil, 1998.

52. ABNT NBR 5739:2018. Concrete-Compression Test of Cylindrical Specimens; Associação Brasileira de Normas Técnicas (ABNT): Rio de Janeiro, Brazil, 2018.

53. ABNT NBR 7222:2011. Concrete and Mortar-Determination of the Tension Strength by Diametrical Compression of Cylindrical Test Specimens; Associação Brasileira de Normas Técnicas (ABNT): Rio de Janeiro, Brazil, 2011.

54. Faubert, J.P.; Gagné, R.; Yahia, A.; Fournier, B. Valorisation de Particules Fines dans les Bétons Compactés au Rouleau et les Bétons Moulés à Sec; Mémoire de maîtrise en génie civil, Université de Sherbrooke: Sherbrooke, BC, Canada, 2013; p. 142.

55. Nagrockienė, D.; Daugèla, A. Investigation into the properties of concrete modified with biomass combustion fly ash. Constr. Build. Mater. 2018, 174, 369-375. [CrossRef]

56. EN 12390-8:2009. Testing Hardened Concrete-Part 8: Depth of Penetration of Water under Pressure; European Committee for Standardization: Brussels, Belgium, 2009.

57. ASTM C157/C157M-17. Standard Test Method for Length Change of Hardened Hydraulic-Cement Mortar and Concrete; ASTM International: West Conshohocken, PA, USA, 2017.

58. Base, C.T.A. Report SR221. 01S; Portland Cement Association: Washington, DC, USA, 1979.

59. Xuan, D.X.; Houben, L.J.M.; Molenaar, A.A.A.; Shui, Z. Cement treated recycled demolition waste as a road base material. J. Wuhan Univ. Technol. Sci. Ed. 2010, 25, 696-699. [CrossRef]

60. Pérez, P.; Agrela, F.; Herrador, R.; Ordoñez, J. Application of cement-treated recycled materials in the construction of a section of road in Malaga, Spain. Constr. Build. Mater. 2013, 44, 593-599. [CrossRef]

61. Sarkkinen, M.; Kujala, K.; Kemppainen, K.; Gehör, S. Effect of biomass fly ashes as road stabilisation binder. Road Mater. Pavement Des. 2018, 19, 239-251. [CrossRef]

62. Berra, M.; Mangialardi, T.; Paolini, A.E. Reuse of woody biomass fly ash in cement-based materials. Constr. Build. Mater. 2015, 76, 286-296. [CrossRef]

63. EN 103 501-94. Geotechnics. Compactation Test. Modified Proctor; European Committee for Standardization: Brussels, Belgium, 1994. 
64. NLT-305-90. Resistencia a Compresión Simple de Materiales Tratados con Conglomerantes Hidráulicos; CEDEX: Madrid, Spain, 1990. (In Spanish)

65. EN 12390-1:2013. Testing Hardened Concrete_Part 1: Shape, Dimensions and Other Requirements for Specimens and Moulds; European Committee for Standardization: Brussels, Belgium, 2014.

66. UNE 103 502-95. Método de Ensayo Para Determinar en Laboratorio el Índice C.B.R. de un Suelo; Spanish Committee for Standardization: Madrid, Spain, 1995. (In Spanish)

Publisher's Note: MDPI stays neutral with regard to jurisdictional claims in published maps and institutional affiliations.

(C) 2020 by the authors. Licensee MDPI, Basel, Switzerland. This article is an open access article distributed under the terms and conditions of the Creative Commons Attribution (CC BY) license (http://creativecommons.org/licenses/by/4.0/). 